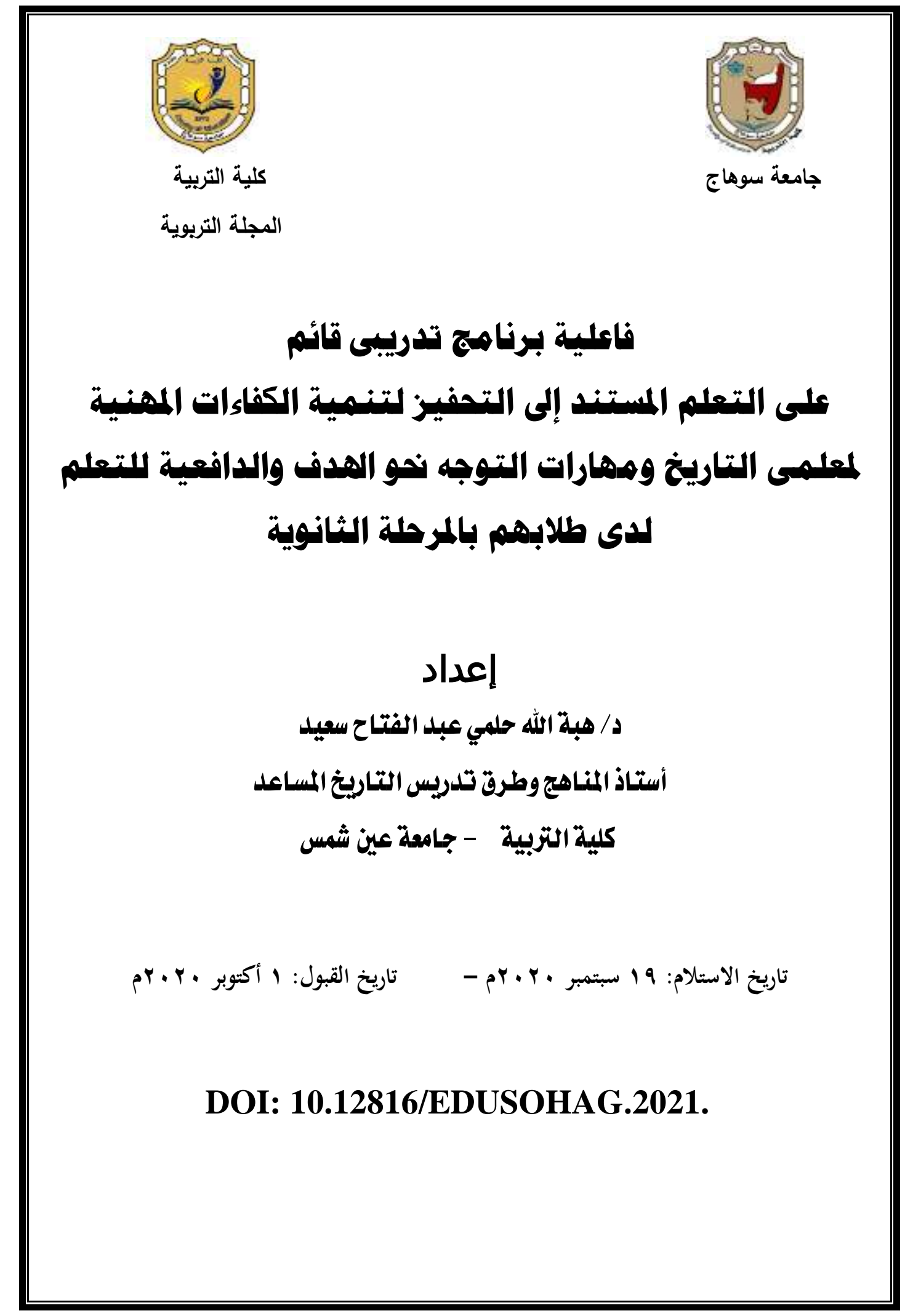


ملخص البحث:

يهرف البحث الحالي إلى معرفة فاعلية إستخدم التعلم المستند إلى التحفيز فى التريس لتتمية الكفاءات المهنية لمعلمى التاريخ ومهارات التوجه نحو الهدف والدافعية للتعلم لدى طلابهم بالمرحلة الثانوية ، و قد تكونت مجموعة البحث من مجموعة من معلمى المرحلة الثانوية و عددهم(IV) معلم و معلمه، و مجموعة من تلاميذ المرحلة الثانوية (الصف الأول الثانوى) وعددهم (• §) طالبه، وقد أستخدمت الباحثه المنهجين الوصفى والتجريبى فى مراحل إعداد البحث و تمثلت مواد البحث فى إعداد قائمة بالإحتياجات التدريبية اللازمة لمعلمى التاريخ لتمئه

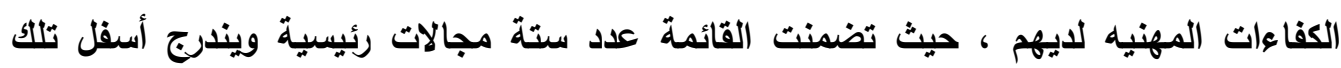
المجالات الأساسية عدد (•r) حاجة تدريبية وأداء يجب على المعلم التمكن منه لتحفيز طلابه لمابه

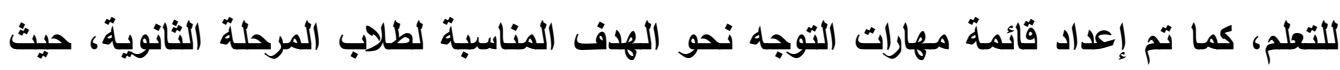
تضمنت خمسة مهارات رئيسية يندرج تحتها عدد من المهارات الفرعية المرتبطة بها بهاب ، وأيضاً

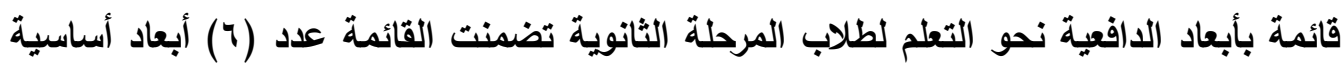

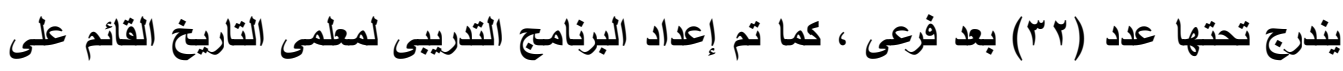

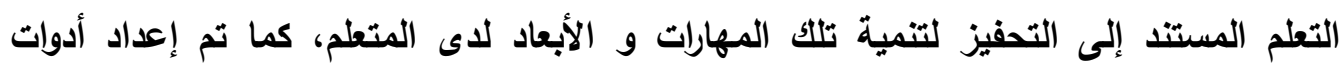
التقويم للبحث متمثله فى بطاقة ملاحظة أداء المعلم للتحقى من إرتفاع مستوى أداء المعلم في

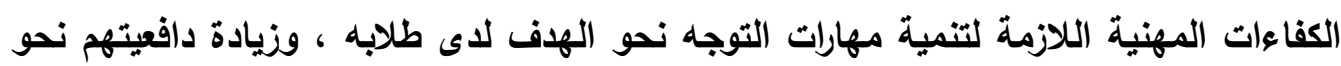

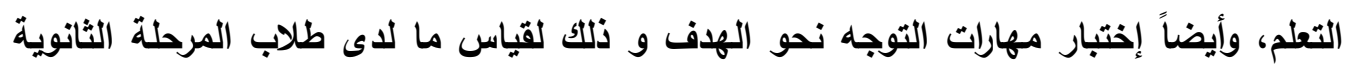
من مهارات عقلية وأدائيه تمكنهم من تحديد أهدافهم (الذاتية وإلحياتية والمعرفية) بنجاح ، كما تم

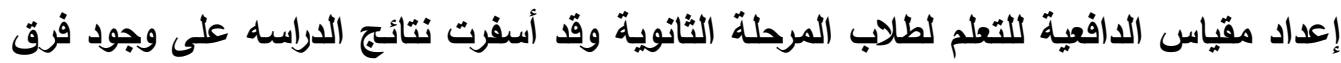

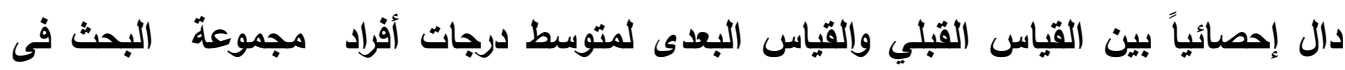

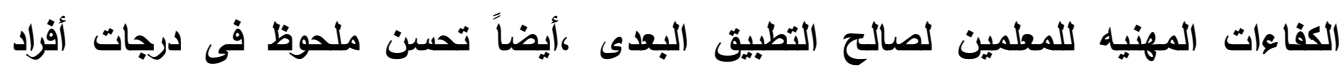
مجموعة البحث من طلاب المرحلة الثانوية فى التمكن من مهارات التوجه نحو الأهداف و زيادة

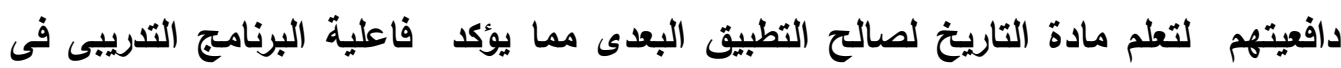

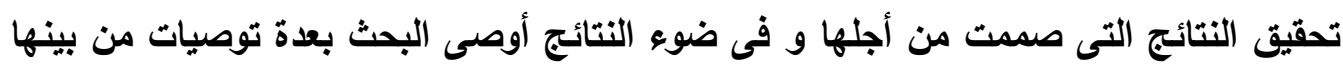

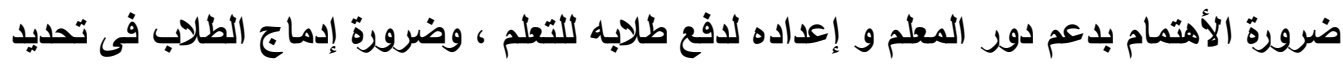
أهدافهم المستقبلية من خلال التعليم المدرسى. الكلمات المفتاحيه: التعلم المستتد إلى لتحفيز - مهارات التوجه نحو الهُف - الدافعية للتعلم. 
The effectiveness of a training program based on stimulation-based learning to develop the professional competencies of history teachers and the skills of goal orientation and the motivation to learn among their high school

The current research aims to know the effectiveness of using stimulation based learningin teaching to develop the professional competencies of history teachers and the skills of goal orientation and motivation for learning among their high school students, and the research group consisted of a group of high school teachers of (17) teachers, and a group of High school students (first grade secondary) and their number (40) students, and the researcher used the descriptive and experimental methods in the preparation stages of the research and the research materials consisted in preparing a list of the training needs necessary for history teachers to develop their professional competencies, and a list of goal orientation skills suitable for high school students has also been prepared, as it includes five main skills under which a number of sub-skills related to it fall, as well as A list of the dimensions of motivation towards learning for high school students Also, evaluation tools were prepared for the research represented in the teacher's performance note card to verify the high level of teacher performance in the professional competencies needed to develop the skills of goal orientation among his students and increase their motivation towards learning and also test the skills of goal orientation in order to measure what the high school students have of Mental and performance skills that enable them to successfully define their goals (subjective, life, and cognitive), and a measure of motivation to learn was prepared for high school students, and the results of the study resulted in a statistically significant difference between the pre-measurement and the postmeasurement of the average grades of the members of the research group in the professional competencies of teachers in favor of the post application There is also a noticeable improvement in the grades of the members of the research group from high school students in mastering the skills of orientation towards the goals and increasing their motivation to learn history in favor of post application, which confirms the effectiveness of the training program in achieving the results for which it was designed, and in light of the results the research recommended several recommendations from Among them is the need to pay attention to supporting the role of the teacher and preparing him to push his students to learn, and the need to include students in defining their future goals through education learning..

Key words stimulation-based learning - goal orientation skills - motivation to learn 


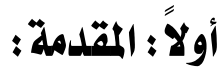

يعد التعليم من الضروريات فى أى مجتمع، حيث أنه يركز بشكل أساسى على الجواتب الإجتماعيه للأفراد ، ورغم النظرة السلبية للتعليم الرسمى التقليدى كونه يركز على التى الحفظ

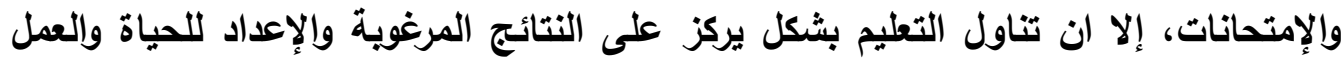
يجعل منه عملية مفيدة للمتعلم وممتعة للمعلم. و يحتاج المتطلم إلى الثعور بحاجته إلى التطليم والرغبة فى الإستزادة منه لفهم العالم المحيط به وتتمية المهارات لايهم ، ولا يمكن ان يحدث ذلك بفاعلية إلا من خلال زيادة الحافز لايه للتعلم وتنمية مشاعرالرغبة فى التعلم مما يتطلب معلم واعى بقدرات متعلميه ولديه الحافز إلى توجيه دافعيتهم للتعلم والعمل. كما يعد المعلم هو أحد المحاور الرئيسية فى العملية التعليمية ، ولم يعد دوره قاصراً

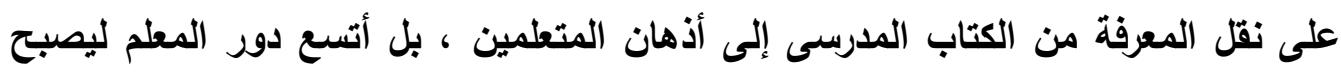

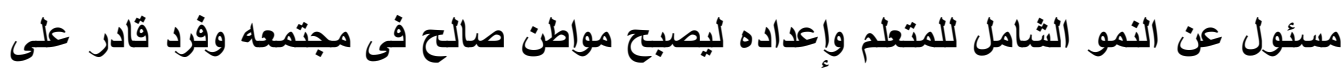

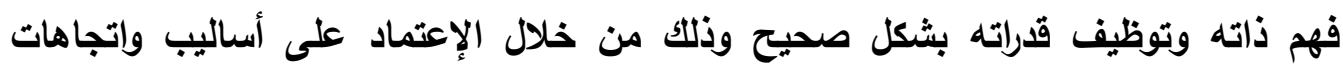

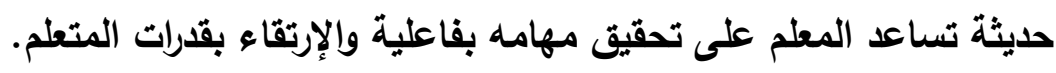

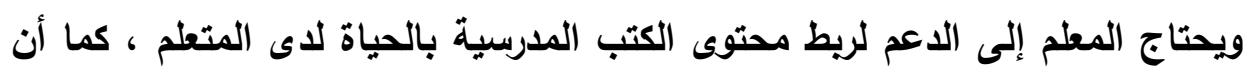

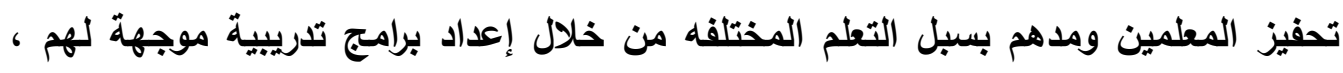

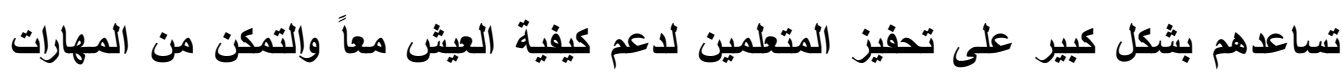

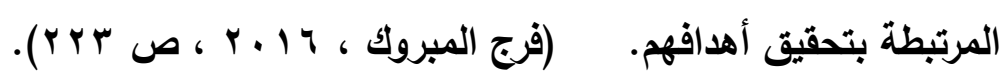
وقد تعددت ادوار المعلم فى العملية التعليمية حتى يستطيع القيام بواجبه اتجاه طلابه، التهابه وكلما أدخلت التطورات على التعليم كلما تطور دور المعلم ليواكب التغيرات ومن أبرز تلثك

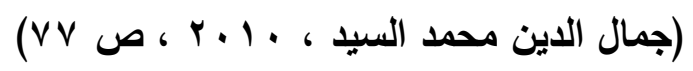

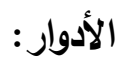
زيادة ثقة المتطم بنفسه. ه المساهمة فى بناء شخصيته السوية. مساعدته على التحول من متلقى للمعرفة إلى باحث عنها. ه تهذيب شخصيته وجطله أكثر قدرة على مواجهة مطالب المستقبل. المساهمة فى فهم ذاته وتوجيه قدراته. 
• مساعدته على تحديد أهدافه المستقبلية ومحاولة الوصول إليها.

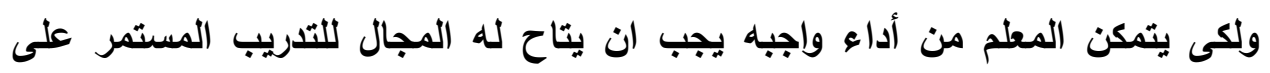

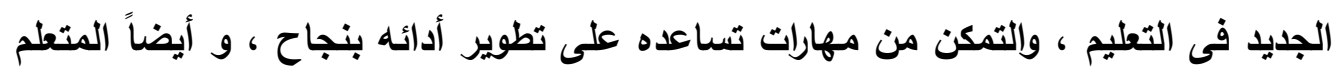

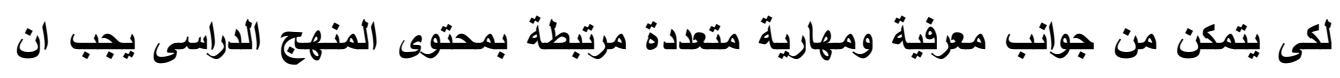
تنمى لديه الدافعية للتعلم وحب العلم والمشاركة فى الأعمال الجماعية.

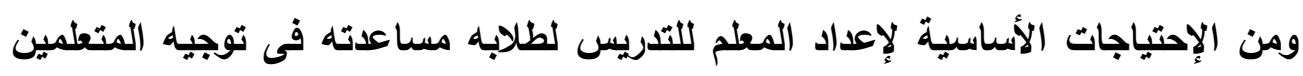

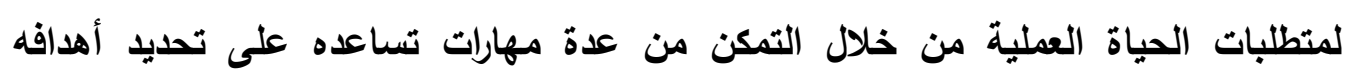
الخاصة والسعى للتوجه إليها وتحقيقها ومن تلك الأهداف: ( ) Nicholas and Others

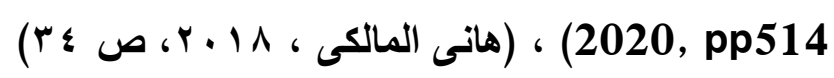
تعزيز السلوك الإيجابى لاى الطلاب.

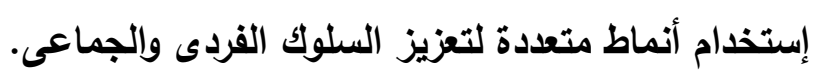
• مراعاة الفروق الفردية بين الطلاب. مراعاة المواهب والقدرات لدى الطلاب. توظيف سبل التعزيز المناسب. العمل على زيادة تكرار السلوكيات الإيجابية لدى الطلاب من خلال التحفيز المستمر .

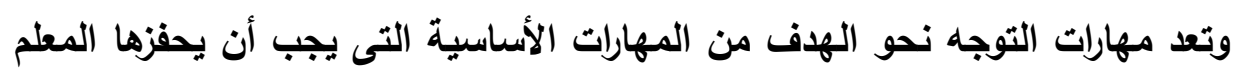
لاى طلابه من خلال توظيف أساليب متعددة ومن تلك المهارات: الريط بين الخبرات السابقة والجديدة. التمكن من المهارات الأساسية لتطوير الأات.

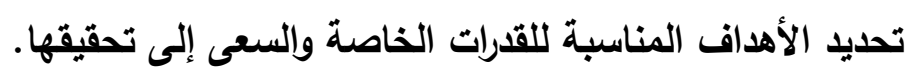
وضع الخطط المناسبة لتحقيق الأهداف. السعى لتحويل الأهداف إلى حقائق.

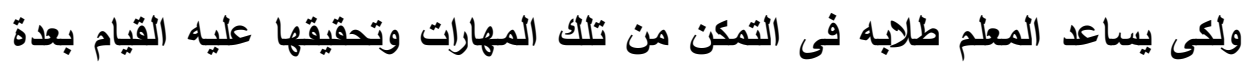

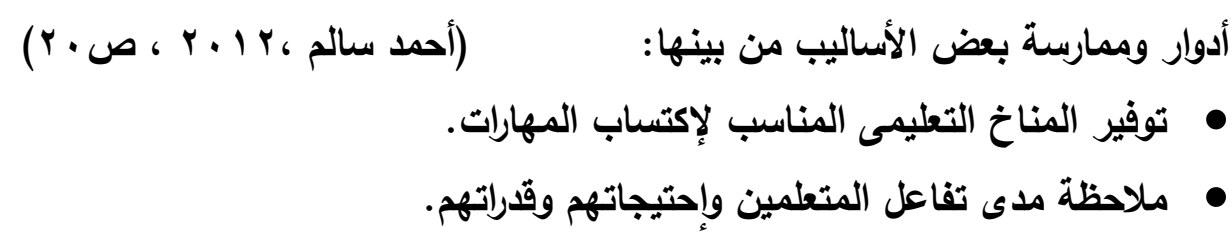


الإدارة الجيدة للصف لممارسة الأنشطة وتطبيق المهارات. تقديم التخذية الراجعة بصفة مستمرة.

•التعاون مع المتعلمين فى تحديد أهدافهم الخاصة المناسبة لقدراتهم الخاصة. تمكين المتعلمين من العمل والدراسة على أساس عقد تعليمى.

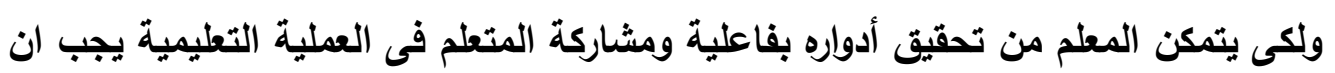

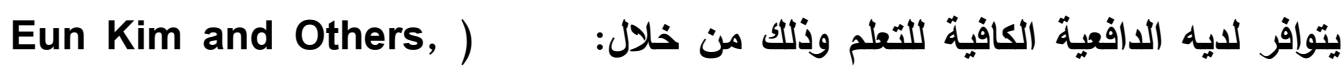
(2019, pp306 تحديد أهدافه بشكل واضح. الحصول على الحافز الكافي للقيام بالعمل بنجاح لتحقيق الأهداف. الشعور بالراحة النفسية والدعم الكافي للإستمرار فى التقدم. استخدام الطرق المناسبة للقدرات الخاصة لإمكانية الشعور بالنجاح. الشعور بالمسئولية إتجاه العمل وتقبل النجاح والفشل. تنظيم الأعمال والوقت والإعتماد على النفس. ويعد التعلم المستند إلى التحفيز أحد الإتجاهات الحديثة وإضافة لأدوار المعلم فى العملية

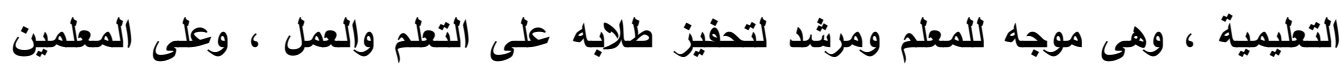
إستخلاص كيفية التحفيز على التعلم من خلال التدريب على ذلك وتوظيف أساليب متعددة

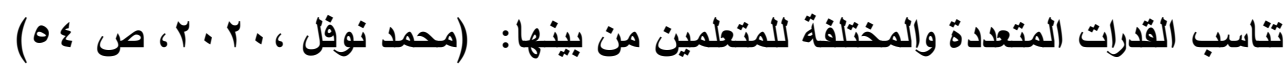
• تطوير إستقلالية الطالب أثناء التعلم. تعزيز التعلم الواعى. خلق بيئة تعلم إيجابية. رفع مستوى التعلم التوضيحى. ضبط النفس والتنظيم الاتاتى. إستخدام الخطأ كجزء من عملية التعلم وليس للعقاب. ويعد التحفيز هو الدافع الأى يدفعنا إلى عمل شئ ما ، وهو كل فعل أو إثلى إنسارة تدفع الإنسان إل سلوك أفضل أو تعمل على الإستمرار فى العمل وعلى ذلك يمكن تعريف التحفيز بأنه: 
كل الوسائل المادية والمعنوية المتاحة لإثباع الحاجات والرغبات المادية والمعنوية لاى لإي

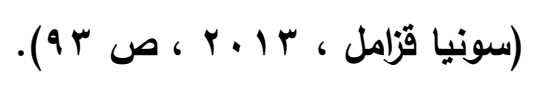

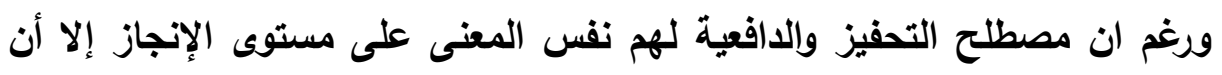

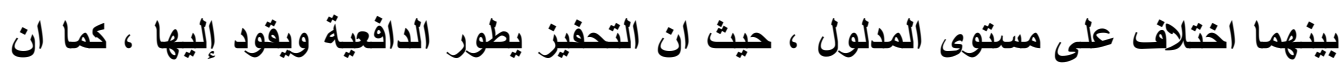
التحفيز يأتى من الخارج اما الدافعية فتنطلق من داخل الفرد ذاته كما أن التحفيز محرك

رئيسى للسلوك للتوجه نحو الهذف. لتهن

أما عن أصناف التحفيز فهى تنقسم إلىى

تحفيز داخلى: مثل المراقبة الذاتية والرغبة والطموحات.

تحفيز خارجى: وهى الدوافع الخارجية مثل المكافأة والعلاوات والسلوكيات.

(Oksna and Others, 2018, pp74-80)

ويالنظر إلى التطور التاريخى للتحفيز نجد أنه ظهر منذ بداية القرن الثامن عشر

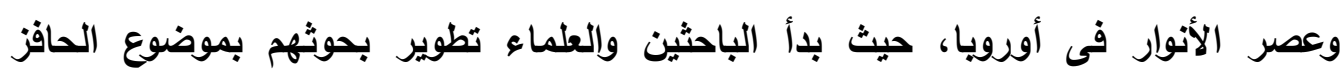

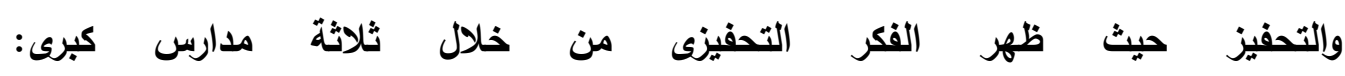

(Hongbiao Yin, 2016, p18)

( ) المدرسة التقليدية: والتى ركزت على الحوافز المادية وهمشت الحوافز المغنوية حيث نظرت إلى الجانب المادى للإنسان لتطوير أدائه.

r مدرسه العلاقات الإنسانية: حيث تنظر للإنسان باعتباره معقد التكوين له مشاعر وأحاسيس ويهتم بالعلاقات والتواصل مع الآخرين فلا يجب التركيز فقط على الجانب الإنبان المادى. (4)

ץ) المدرسة الحديثة : والتى دعت إلى ريط الحوافز بالنتائج التى يتم تحقيقها ونادت بضرورة إختلاف أساليب التحفيز وتتوعها وفقا لمستوى الأداء.

(وعلى مستوى المتعلم ومن أجل تحقيق الكوامن الداخلية للمتعلم ودفعه نحو التحفيز كان لابد من مراعاة عدة مبادئ: ( David and Abigail, 201, pp 1:21) ، (ريجان

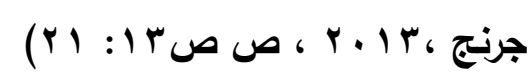

إحترام المميزات الجسدية والعقلية والنفسية للمتعلم ومراعاة التدرج بشكل يتيح للمتعلم الإستخدام الأمثل لإمكاناته وقدراته. 
برمجة الأنشطة الصفية والتى يكون فيها المتعلم مهيأ لبذل جه مع مراعاة الزمن ونوع

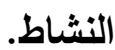

توفير البيئة التعليمية الآمنة والمحفزة للعمل حيث يسود بها الأمن والأمان والعلاقات السليمة بين كافة أطراف الموقف التعليمى.

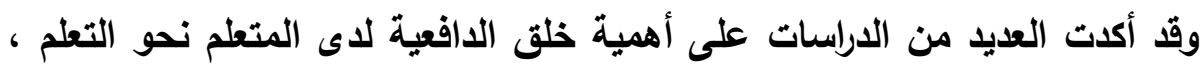
وكذلك دور المعلم فى تحفيز طلابه لتحقيق أهداف تعليمية أفضل وتوظيف قراته لتحقيق أهدافه الخاصة و من بين تلك الدراسات:

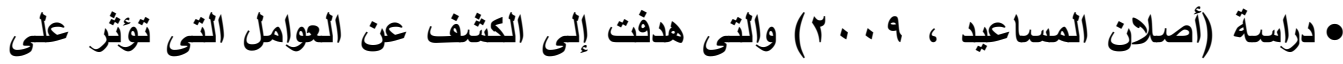
دافعية التعلم لدى طلبة جامعة آل البيت وقد أسفرت النتائج عن ان هناك عدد من العوامل المؤثرة فى توجيه دافعية المتعلم للتعلم من بينها إدراك الفرد لقدراته ، الخبرات والعلاقات الإجتماعيه ، الرغبة فى التفوق. وقد أوصت الدراسة بتفعيل دور المعلم فى توجيه طلابهم وإثارة دافعيتهم نحو التعلم من خلال تغيير أساليب التدريس التقليدية وتوظيف أساليب تساعد على الحث على التعلم وتحفيز المتعلمين. دراسة (Chia, Hui and Others, 2017) حيث طبقت دراسة شبه تجريبية " دراسة حالة " على مجموعة من المتعلمين للتحقق فى تأثير القدرة التتبوئه لتحفيز المتعلم على الإنجاز بإستخدام الألعاب التعليمية المحمولة لتعلم اللغة الإنجليزية ودمج المواد التعليمية فى سياق قائم على اللعبة وتثبيته على الأجهزة المحمولة ، وقد أسفرت الاراسة عن فاعلية أسلوب التحفيز فى دعم التعلم لدى التلاميذ وزيادة الدافعية لايهر. دراسة (Ludmila Miklankov, 2018) وقد هدفت الدراسه إلى تحليل مستوى المهارات الحركية لدى الأطفال فى سن ما قبل المدرسة فى سياق التحفيز لأداء الانشطة البذنية فى العى المدرسة. وقث تكونت مجموعة البحث من باج طفلاً بمتوسط عمر من خمس إلى ست سنوات وقد أسفرت النتائج على فاعلية التحفيز على دعم النشاط الحركى لاى الأطفال.

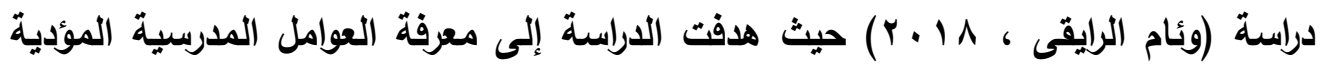
إلى إنخفاض الدافعية للتعلم وقد أكلت الدراسة على أهمية تهيئة البيئه الصفية المشجعة إلهات للتعلم وضرورة أن تمثل المعلمة جزع من فريق عمل متكامل بالمؤسسة التعليمية لخلق 
الحافز للتعلم ورفع مستوى الدافعية لدى الطالبات وقد أسفرت نتائج الدراسة عن تحسن ملحوظ نتيجة توفير مصادر التعلم الحديثة وتطوير أداء المعلمات.

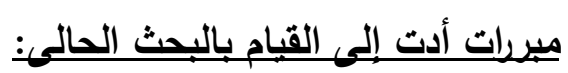

نتائج العديد من الاراسات التى أكدت على ضرورة تطوير الأداء التدريسى للمعلم أثناء

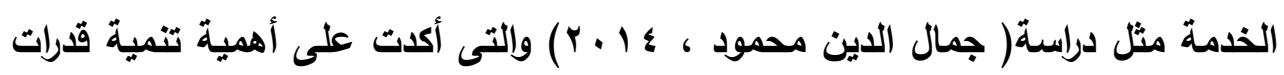
معلمى التاريخ من خلال التمكن من مهارات إستخدام شبكات التواصل الإجتماعى وقد أوصت الدراسة بإعداد برامج تدريب لمعلمى التاريخ تدعم المهارات والكفاءات الادائيه لاى المعلمين.

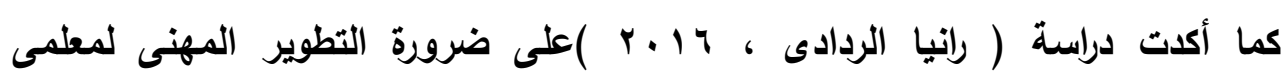
الدراسات الإجتماعيه فى ضوء متطلبات التعليم الرقمى والتى أثارت إلى أهمية التطور المهنى المستمر لمعلمى الدراسات الإجتماعيه لزيادة المعرفة المهنية لديهم واتجاهاتهم نحو المهنة مما يساعد على عملية التدريس من أجل تعلم جيد.

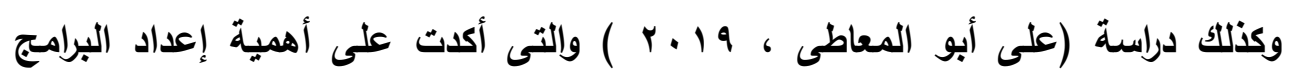

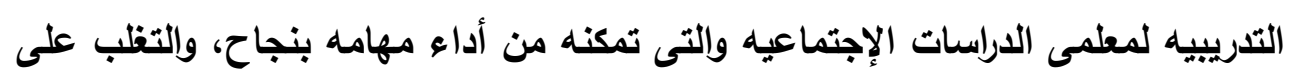
المشكلات التى تواجهه أثناء العمل. واوصت الدراسه بإعداد دراسات أخرى تمكن المعلم من المهارات اللازمة لأداء العمليات المختلفة داخل الفصل الاراسى. وأيضاً نتائج العديد من الدراسات التى أكد على ضرورة تتمية مهارات متعددة لاى المتعلم

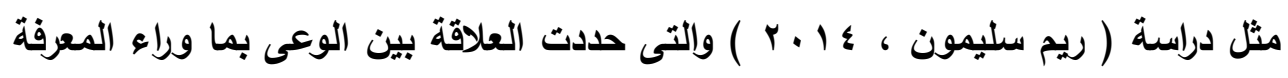

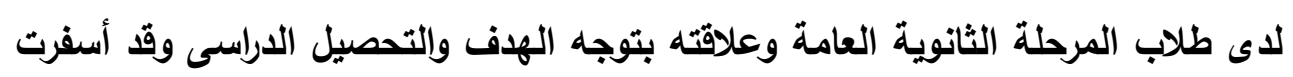
الاراسة عن وجود علاقة دالة بين مهارات ما وراء المعرفة والتوجه نحو الهدف والتحصيل وقد أوصت الدراسة بضرورة تدريب معلمى المرحلة الثانوية على توجيه طلابهم نحو أهدافهم وتوظيف أساليب متعددة لتحقيق ذلك.

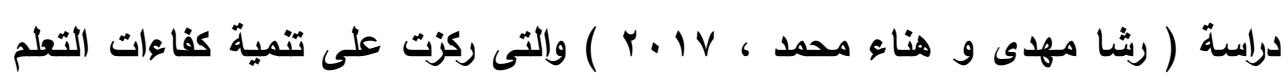

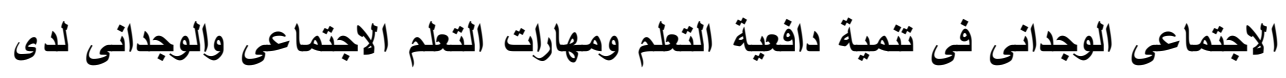

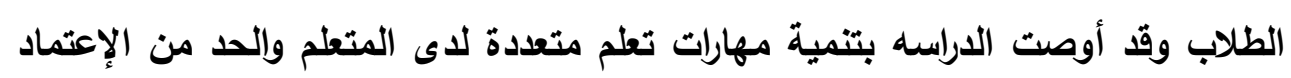
على الحفظ والتذكر . 
وأيضاً دراسة كلاً من (إسلام أنور ونسرين محمد ، 11 • ب) والتى هدفت إلى تحديد

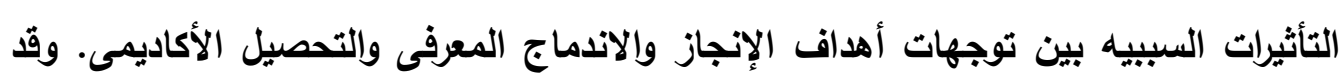

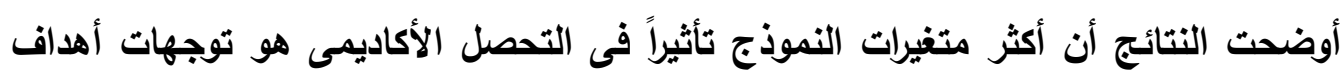
الآخر، كما كان له الأثر الكبير على الإندماج المعرفى العميق.

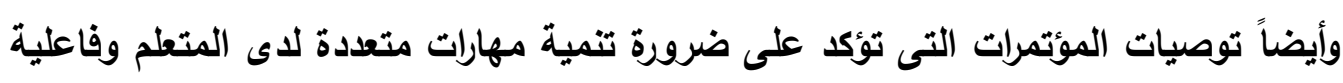

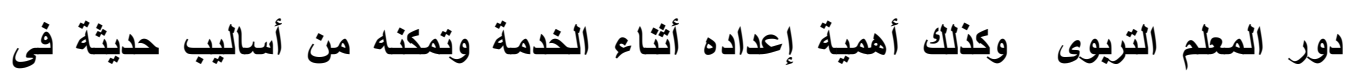
التدريس.

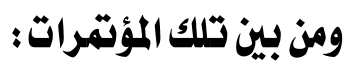
المؤتمر الخامس لإعداد المعلم: جامعة أم القرى " مكة المكرمة " بعنوان " إعداد وتدريب

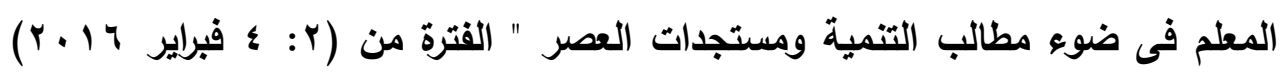
وقد جاءت أهداف المؤتمر متضمنة: - - تحديد المعايير والمواصفات اللازمة للمعلم. - إبراز أهمية تدريب المعلم قبل وأثناء الخدمة. - إبراز أهمية إعداد المعلم فى ضوء مجتمع المعرفة. وقد أوصى المؤتمر بضرورة الإعداد الأمثل للمعلم من خلإل إعل التدريب المستمر والإستناد على أساليب حديثة لتطويز أداء المعلم أثناء الخدمة بما ينعكس على الاعلى أداعه الأهن التدريسى وتحقيق أهداف التعلم لاى الطلاب.

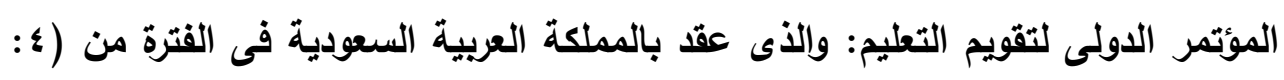

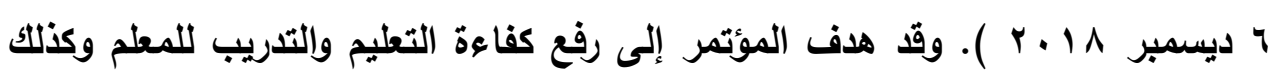

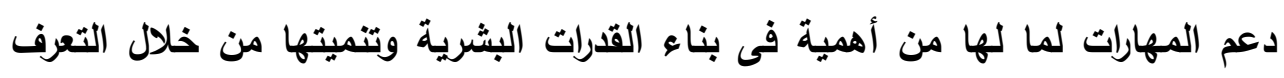

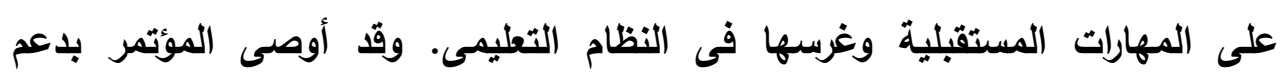

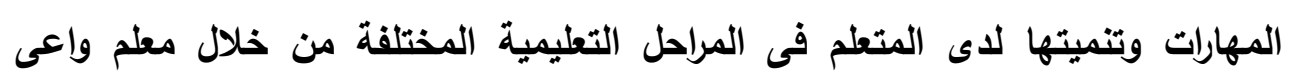
بقرات متعلميه ولديه الحافز الكافى لتنمية تلك المهارات لايهرم.

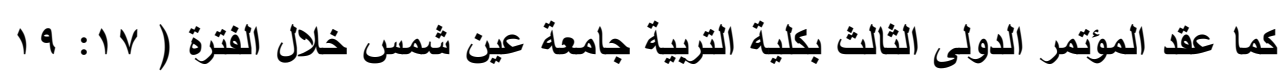

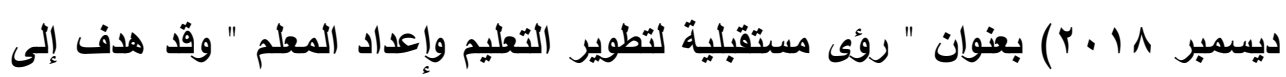

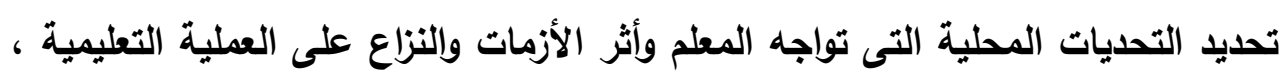


وقد أوصى المؤتمر بضرورة تحقيق التميز فى التعليم وتوظيف أنماط حديثة للتطم غير الأنماط التقليدية مثل التعلم الإلكترونى والتعلم مدى الحياة.

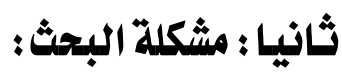
تتحدد مشكلة البحث في" قصور الكفاءة المهنيه لاى مطمى التاريخ فى تنمية الدافعية

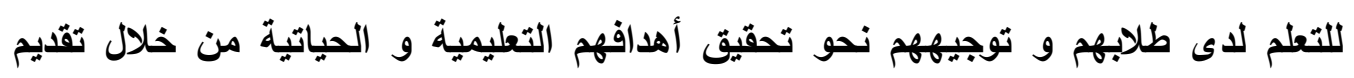
التحفيز الكافي والإستناد إلى قدراتهم الخاصهة

وللتصدي لهذه المشكلة حاول البحث الحالي الإجابة عن السؤال الرئيسي التالي:

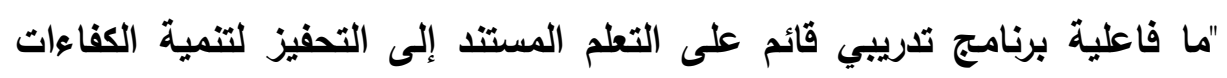

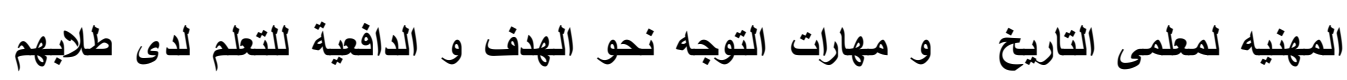

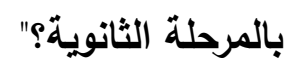
ويندرج من السؤال الرئيسي الاسئله الفرعيه التاليه:

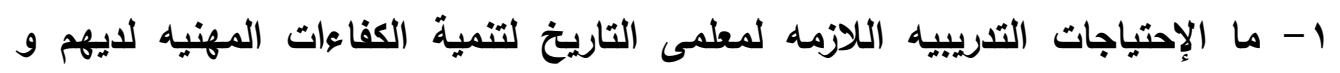

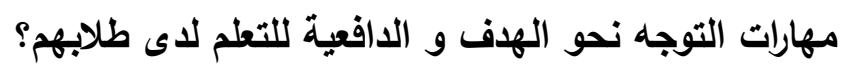
r - ما مهارات التوجه نحو الهـف اللازمة تنميتها للى طلاب المرطلة الثانويةج

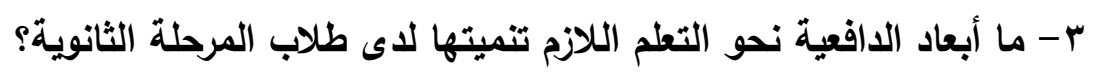

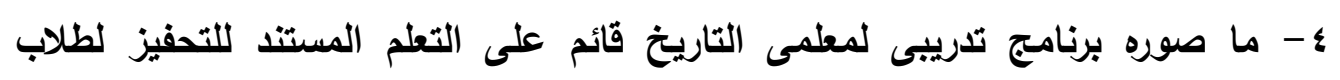

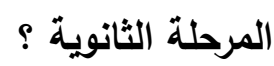

ه- ما فاعلية البرنامج التدريبى لمعلمى التاريخ فى تتمية الكفاعات المهنيه لايهه ؟

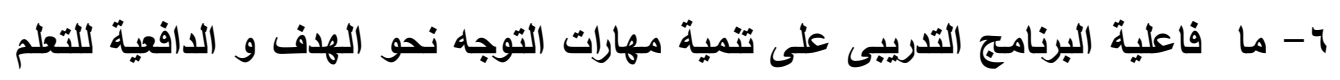

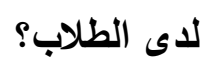

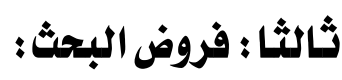
1- يوجد فرق دال إحصائياً بين القياس القبلي والقياس البعدى لمتوسط درجات أفراد

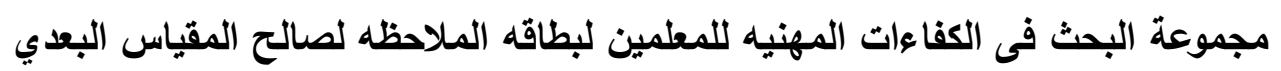

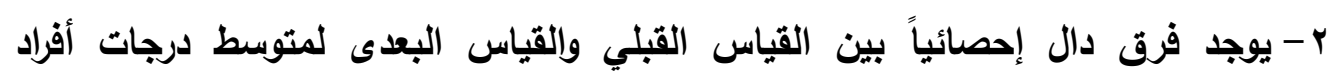

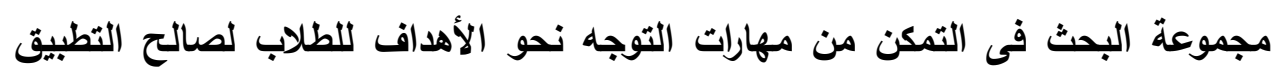

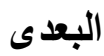


ب- يوجد فرق دال إحصائياً بين القياس القبلي والقياس البعدى لمتوسط درجات أفراد مجموعة البحث فى دافعية الطلاب لتعلم مادة التاريخ لصالح التطبيق البعدى.

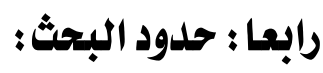

اقتصر البحث الحالي على الحدود التالية:

- حدود مكانيه: مجموعة من معلمي التاريخ بمدارس إدارة مدينه نصر و الوايلى و شبرا التعليمية بمحافظه القاهرة.

- حدود موضوعيه: إعداد قائمة بمهارات التوجه نحو الهدف اللازم تنميتها لاى طلاب

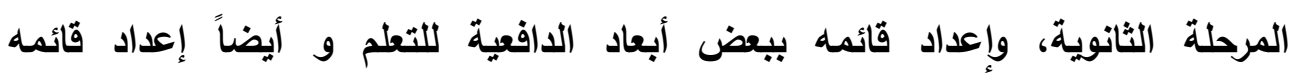

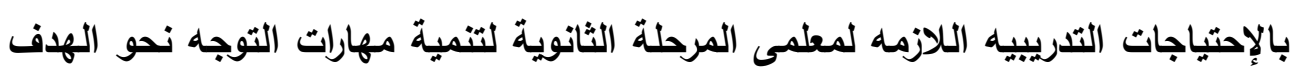
و الدافعية للتعلم لاهى طلابهم.

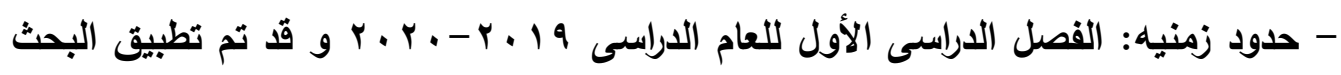

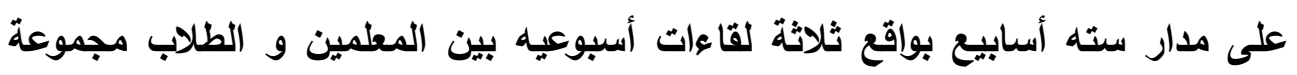
البحث .

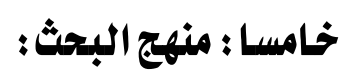
إعتمد البحث الحالي على كلاً من:

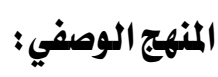

أستخدم فى تحديد الإطار النظري للبحث ووضع تصور ببرنامج لتنمية التحفيز لتنمية

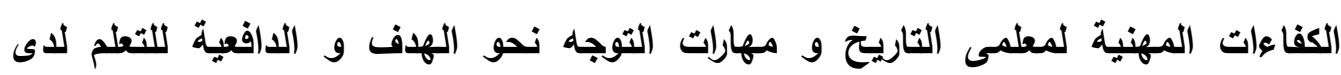
طلابهم. المنهج التجريبي: أستخدم فى تطبيق البرنامج وإجراء التطبيق القبلي والبعدي لأدوات التقويم ثم حساب نتائج التطبيق إحصائياً والمقارنة بينهم. 


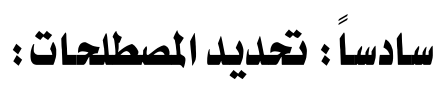

:التعلم المستتد إلى التحفيز :

" هو نوع من التعلم يهدف إلى تحقيق الأهداف التربية من خلال رفع المهارات الإنتاجية

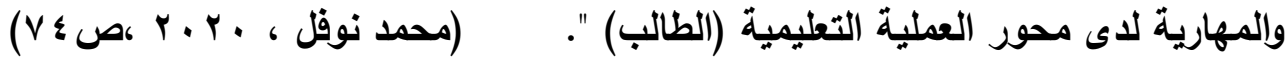
المفهوم الإجرائى للبحث الحالى للتعلم المستثد إلى التحفيز هو : " أحد الاتجاهات الحديثه فى التدريس التى يوظقها المعلم لتحفيز الطلاب أثناء التعلم

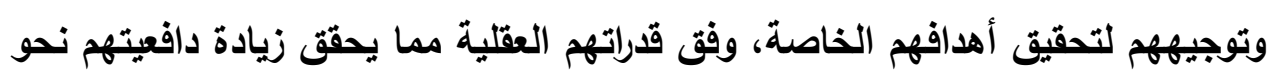

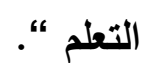

* مهارات التوجه نحو التهف:

" هى كل المهارات التى يسعى المتعلم إلى تحقيقها و تدفعه ان يبذل كل ما لديه من قدرات

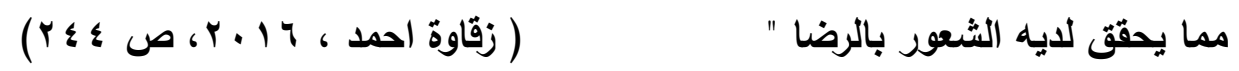
ويعرفها البحث الحالمى بأنها:

" دوافع داخليه لدى المتعلم تظهر فى شكل أداعات يقوم بها للتوجه نحو تحقيق تلك الدوافع مما ينعكس عليه بالانجاز والنجاح."

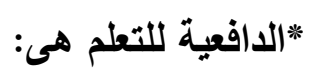

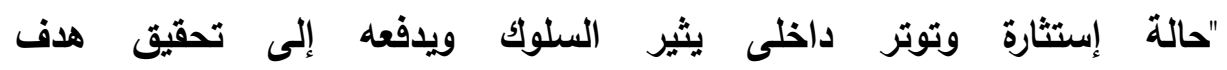

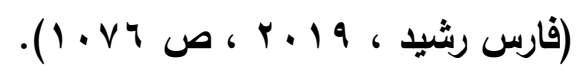

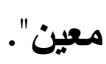
ويعرفه البحث الحالى بأنها: " طاقة كامنة لاى المتعلم تظهر عند توافر بيئة تعلم نشطة تحفز تلك الطاقة وتوجهها نحو تحقيق عدة أهداف تعليمية ومستقبلية ".

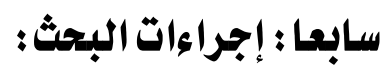
يسير البحث الحالي وفق الإجراءات التالية: ا - تحديد قائمتين أحدهما بمهارات التوجه نحو الههف والأخرى بأبعاد الدافعية للتعلم وإللازم تنميتها لاى طلاب المرحلة الثانوية. ويتم ذلك من خلال: 


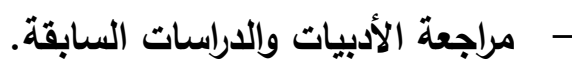

- - مراجعة الإتجاهات العالمية والتي تناولت أهميه تنمية مهارات التوجه نحو الههف و واليات الأفعية نحو التعلم

- - إستطلاع رأي الخبراء والمتخصصين لضبط الفطم القائمة. r - إعداد قائمة بالإحتياجات التدريبية اللازمه لمعلى التاريخ لتنمية كلا من مهارات التوجه نجو الهدف واللدافعية للتعلم لاى طلابهم r- إعداد برنامج تدريبى لتدريب مجموعة البحث من معلمى التاريخ بالمرحلة الثانوية على

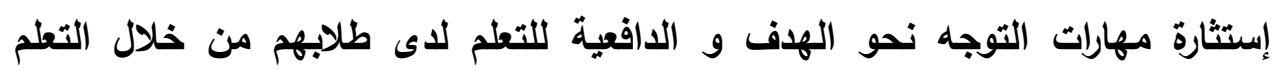

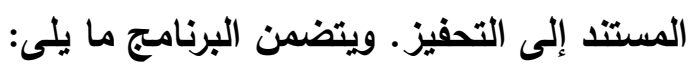

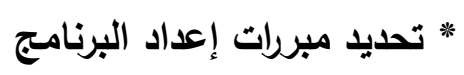

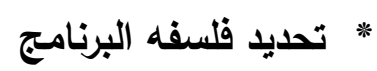

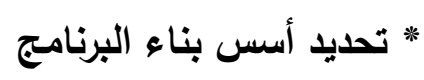

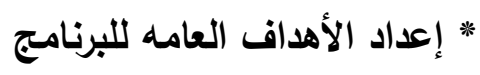

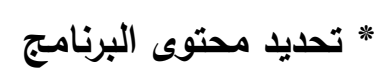

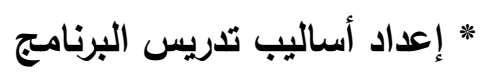
* إعداد أساليب تقويم البرنامج

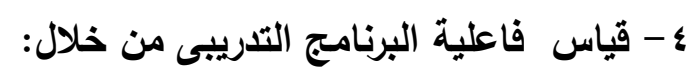

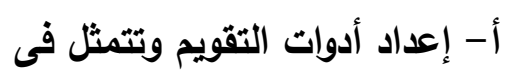

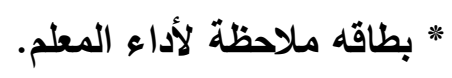

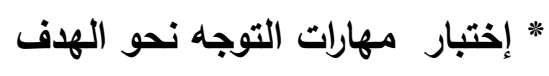
* مقياس الادفعية للتعلم لدى الطلاب. ه - تطبيق أدوات التقويم قبليا

צ- تطبيق البرنامج التدريبي على مجموعة البحث V - تطبيق أدوات التقويم بعديا.

^- رصد النتائج ومناقشتها إحصائياً وتفسيرها 9- تقديم التوصيات والمقترحات 


$$
\text { يـهذف البحث الحالي إلحى: }
$$

1 - تحديد أثز توظيف التعلم المستند للتحفيز على تنمية الكفاءات التدريسيه لاى معلى التاريخ بالمرحلة الثانوية وإنعكاس ذلك على أدائهم المهنى.

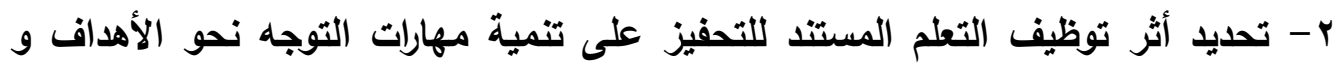
الدافعية للتعلم لاى طلاب المرحلة الثانوية.

\section{تاسعاً : أهمية البحثث}

\section{قـ بفيد البحث الحالي فئه}

1 - تقديم برنامج تدريبي لمعلمي التاريخ قائم على التعلم المستند للتحفيز لتنمية العديد من الكفاعات التدريسيه لايهم للتعامل مع طلابهم بنجاح.

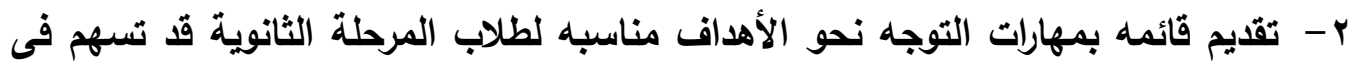
توجيه المتعلم نحو أهدافه المستقبلية فى ضوء قدراته الخاصه.

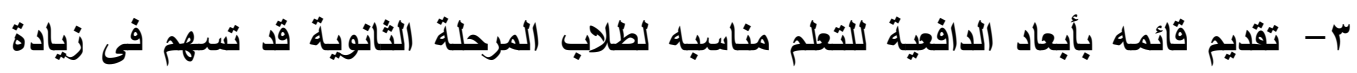
الاقبال على تعلم مادة التاريخ و الاستفادة من أحداث الماضى فى فهم الحاضر و التوجة

$$
\text { نحو المستقبل. }
$$

\section{المحور الأول : الإطار النظرى للبحث}

يتناول هذا المحور تحديد التعلم المستتد للتحفيز من حيث المفهوم والأهميه ، كأحد الإتجاهات الحديثه للتدريس والرفع من قدرات المعلم التدريسية ، مما ينعكس على أدائه التدريسى و يحقق التحفيز الكافي لطلابه لتحديد أهدافهم التدريسية و الحياتية و دافعيتهم للتعلم,

$$
\begin{aligned}
& \text { التعلم المستثد إلى التحفيز ( المفهوم والأهمية ): } \\
& \text { *مفهوم التعلم المستتد إلى التحفيز : }
\end{aligned}
$$

هو أحد الاتجاهات الحديثة فى التدريس الذى يوظقها المعلم من خلالها الإستراتيجيات التعليمية التى تعمل على توليد إنتباه الطلبة وأدائهم فى مختلف المواد (Kathleen Cushman, 2014, p.5) 
اما عن مفهوم التحفيز فهو:

" طاقة نابعة من المتعلم أو من البيئة التعليمية توجه المتعلم لأداء بعض المض مهاريز المهارات

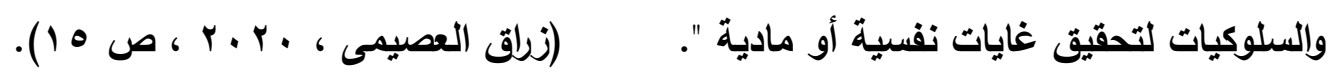

$$
\text { وفى مفهوم آخر التحفيز هو: }
$$

" قوة دافعة منشطة للتعلم تولد لاى المتعلمين من خلال توظيف المعلم لإستراتيجيات محفزة

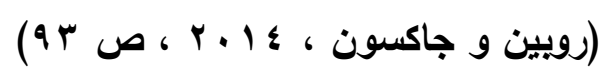
للاطلاب ".

ويعد التعلم المستند إلى التحفيز هو إتجاه حديث لتغيير أساليب التعلم من خلال توظيف أساليب غير تقليدية من أجل الوصول إلى نظام تعليمى متطور ، ويكون المعلم له هونه

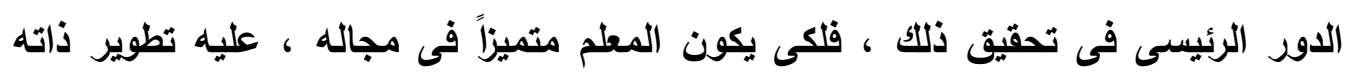
وتوظيف الجديد فى المجال التعليمى. ولكى يجعل المعلم طلابه أكثر إقبالاً على حب التعلم عليه أن يحفزهم من خلال

توظيف طرق متعددة: الإستفادة من معرفة إحتياجات الطلاب حيث يتمكن المتعلم من التعلم بشكل أفضل عندما تلبى الحوافز دوافعه الخاصة. جعل الطلاب مشاركين بفاعلية فى عملية التعلم من خلال أداء مهمات متعددة وحل المشكلات وإتخاذ القرارات حيث أن السلبية تحد من قدرات المتعلم وحافزه نحو التعلم. مشاركة الطلاب فى تنظيم العمل داخل حجرة الدراسة من خلال مناقثتهم حول ما يجعل الاراسة أكثر أو أقل حماساً ودافعية نحو التعلم، حيث يحصل المعلم على عوامل دمل متعددة

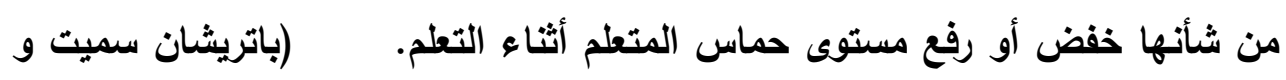

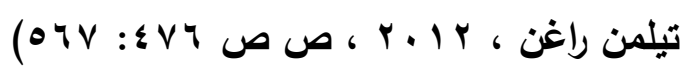

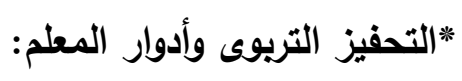

يعد التحفيز التربوى هو أهم عوامل إيجاد الدافعية نحو التعلم لاى الطلاب، والتحفيز الإيجابى يأتى بالعديد من النتائج المرغوب بها لألى المتعلم.

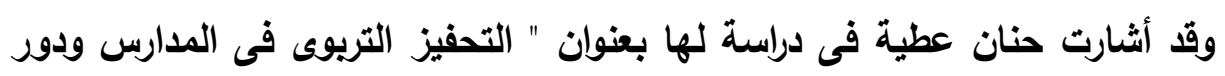

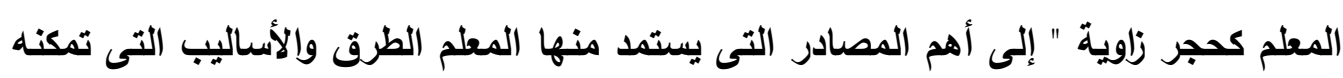

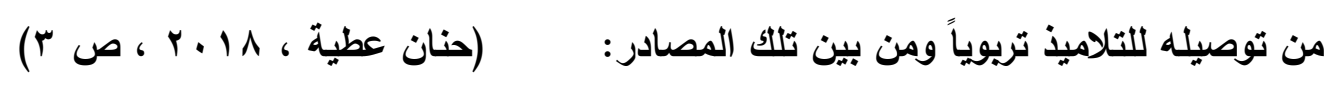


ثقافة المجتمع والقيم العليا به.

دور الفرد كمواطن فى المجتمع.

مفهوم الأات لاى المتعلم.

دور الأسرة ومؤسسات المجتمع المدنى تريوياً.

البيئة المدرسية وادوار المعلم بها.

كما أكلت دراسات آخرى مثل (Libby Gevard and Others, 2016) بأن أسلوب المعلم غير المباشر فى تفاعله (Others, 2016 Danial Nadon and )، مع طلابه وتوجيهه لهم يعتبر من العوامل المهمة والمحفزة إجتماعياً فى غرفة الدراسة ، وعلى العكس المعلم المتجهم الناقد غير المهتم برغبات ومصالح طلابه يثير لايهم الشعور بالعزوف عن التعلم ويزيد من المشاكل الصفية. ولكى يحقق التحفيز فاعلية عليه ان يلتزم ببعض الضوابط من بينها: (رمضان

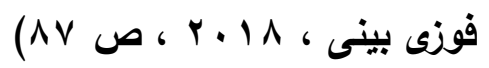
التبعية: وهو ان يلى الحافز مباشراً العمل المراد القيام به. الحجم والنوع: ان تناسب حجم الحافز ونوعه للعمل من حيث الحجم والنوع. إدرالك سبب التحفيز : وهو فهم الطالب لماذا تم تحفيزه. الثبات: ان يحفز الطالب فى نفس المجال للمزيد من دعم القيام به. مراعاة مستوى المتعلمين: ان يطالب المتعلم بما هو قادر على القيام به.

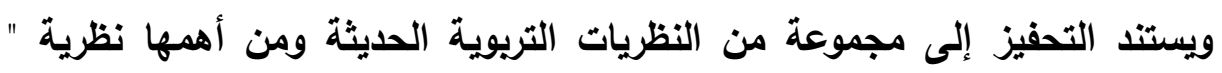
ماسلو " للحاجات MASLOW وهى من أهم النظريات فى مجال تطبيق الحاجات الإنسانية فى عدة مستويات متدرجه على النحو التالى:

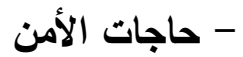

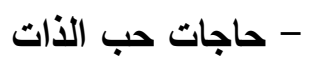

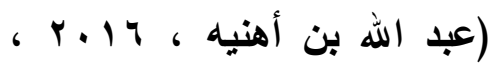

- الحاجات الطبيعية

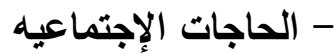
-

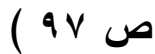

وعلى المعلم ان ينوع فى أسالب التحفيز بحيث يراعى الإحتياجات المختلفة للمتعلم،

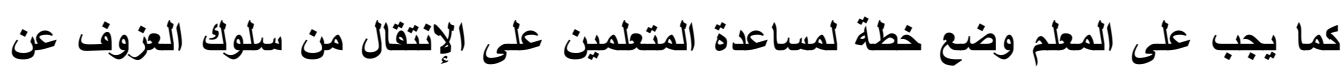


التعلم إلى سلوك التحفيز للتعلم داخل غرفة الدراسة من خلال توظيف إستراتيجيات تساعد

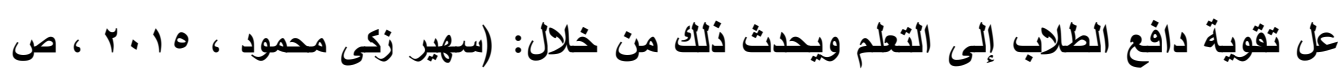

تحديد سبل الاستثمار الصحيح لقدرات المتعلم.

الإعداد الجيد لغرفة الدراسة.

فهم سلوكيات وقدرات الطلاب وطاقاتهم الكامنة.

استثمار قدرات الطلاب وإثارة دافعيتهم نحو التعلم. وفئ.

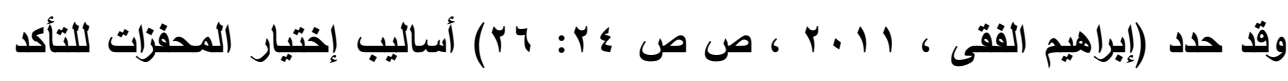

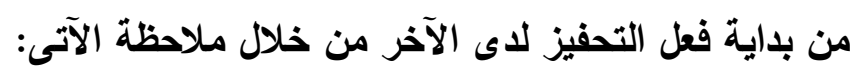

هان يكون الفرد فى أحسن حالاته أثناء عملية التحفيز، لذلك على المعلم خلق بيئة التعلم المناسبة لجذب إنتباه المتعلم للخروج من حالته الإنفعالية قبل موقف التعلم إلى حالة الته الإستعداد للتعلم.

• أن يقدم المحفز للقرد وهو فى قمة الإستعداد لإستقباله وعلى المعلم فى ذلك أن يلاحظ

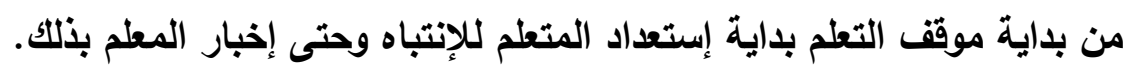

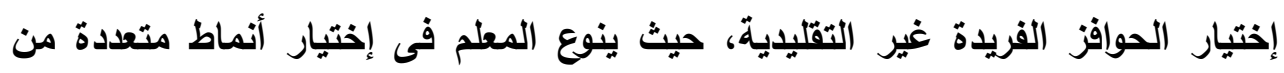
الحوافز تناسب الإختلافات بين المتعلمين فى السمات والقدرات وتدفعهم إلى المزيد من

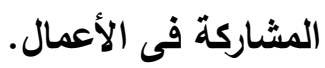

مراعاة الدقة عند تكرار المثير، فعند إختيار المعلم لأحد المثيرات للتحفيز ويثبت له

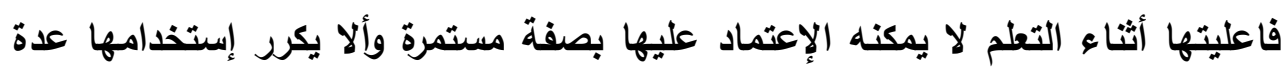
مرات بهرف الحصول على نفس الإستجابة أول مرة. ومما سبق يتضح أن هناك عدة عوامل تؤثثر على حماس الطالب للتعلم من بينها: (Johnson Davion, 2017, p. 46 ،(Fatih Koca, 2016, p.20) أسلوب المعلم فى تحفيزه للتعلم. مضمون الارس وقيمته لاى المتعلم. انتظام الدرس وييئة التعلم. مستوى صعوية الدرس وقدرات المتعلمين المختلفة. 
المشاركة الفعالة للمتعلم أثناء التعلم. العلاقة بين المعلم والطالب. توظيف النماذج والأمثلة المناسبة والمفهومة لدى الطالب. ومن الأهداف التى يسعى أسلوب التعلم المستند إلى التحفيز إلى تتميتها لاى

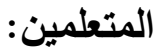
( ) رفع الروح المعنوية لاى المتعلمين: حيث أن الدافع للإنجاز والرغبة فى النجاح تكمن فى الموقف الذى يمر به المتعلم أثناء التعلم وكذلك إعداد بيئة التعلم المناسبة له. r إثباع الحاجات: عندما يشعر الفرد من داخله بالحاجة إلى الشئ يسعى إليه، وكذلك

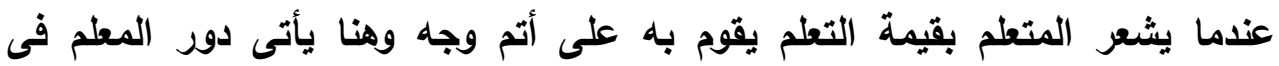
تثخيص حاجات المتعلم وظروف التعلم. r) رفع الأداء: من خلال تنوع أساليب التحفيز وضبط جودة الأداء، فكلما كانت الحوافز المعطاة تتفق ونوعية الحاجات التى يريد المتعلم إثباعها كلما زاد فاعلية الأداء

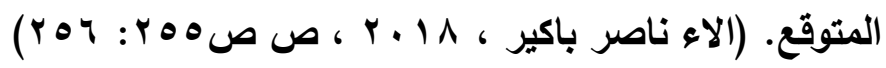
كما أن هناك ثنلاثة عناصر أساسية للتحفيز r) (القدرة على القيام بالعمل.

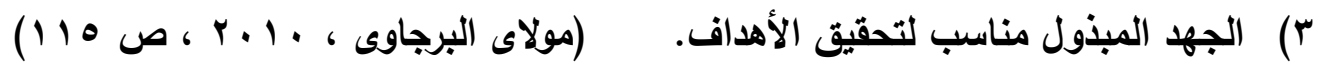
ومن الإستراتيجيات التى بعتمد عليها المعلم فى تحفيز طلابه أثناء التعلم: هاهئ توجيه المتعلمين إلى أهمية المادة وقيمتها لخلق الحماس لاى المتعلم لدراستها. توطيا العلاقات الصحية مع المتعمين ومعرفته بقدراتهم. الإعتماد على المتعلمين بعض الوقت فى إدارة الصف لخلق الثقة بالنفس لايهم. تنمية مهارات البحث والإكتشاف لاى المتعلمين. الإعداد لأنشطة العمل الجماعى والتعاون بين المتعلمين. صياغة الأهداف بشكل محدد ومشاركة المتعلمين فى تصميمها والوصول لها. إستخدام النقد البناء عند توجيه المتعلمين. التركيز على إهتمامات الطلاب وقدراتهم. 


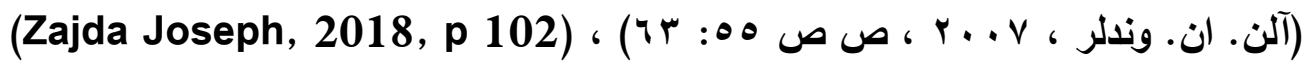
ومما سبق يتضح ان المتعلم غير المتحمس للتعلم لا يستطيع التقدم، وان تحفيز المتعلمين بسبل متعددة يساعدهم على النجاح، وعلى المعلم بذل جها أثناء العمل لإظهار الحماس المطلوب لاى المتعلم وأن يحافظ على هذا النشاط أثناء العمل. • مهارات التوجه نحو الأهداف (التعليمية والحياتية): إن فكرة صباغة الأهداف تقوم على مبأين أساسينين:

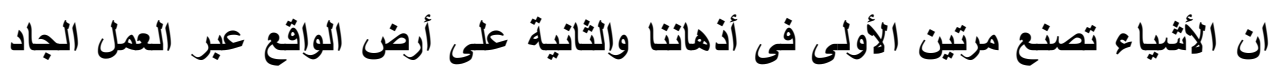

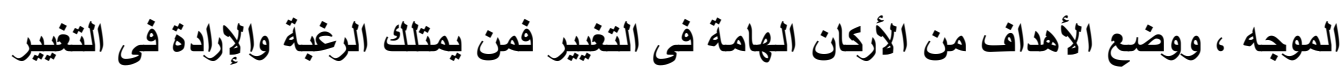
دون صياغة أهداف محدة فقد يبذل جه كبيز وقد لا يصل إليها ويفقد الدافعية للتغيير.

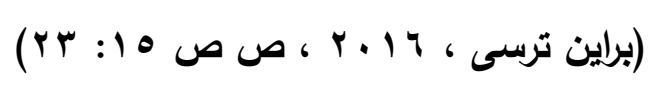

ويعد تحديد الأهداف التعليمية والحياتية من الأمور الهامة فى حياة الفرد وقا يرجع

$$
\text { ذلك إلى عدة أسباب: }
$$

صياغة الأهداف الجيدة هى مصدر لتحفيز الطاقة للعمل. الأهداف توضح الروئة والطريق وتعد معيار للحكم على النجاح. إعداد الأهداف يحدد الجها المبذول ويمنع التثتت.

تحديد الأهداف يعنى وعى الفرد بذاته وطاقاته وتوجيهها بشكل صحيح.

(Yuka Mlkami, 22, pp. 28:48)

وعلى ذلك هناك علاقة قوية بين تحديد الأهداف وتحقيق النجاح فالانسان الناجح هو الأى يسير ويتحرك وفق أهداف مرسومة مسبقاً ولتحقيق النجاح وفقاً للأهداف يجب مراعاة الآتى :

تحديد الأهداف المناسبة للقدرات. ان تكون الأهداف واقعية ويمكن إنجازها. ان تكون الأهداف مرنة وقابلة للتعديل. إمكانية قياس ما تم إنجازه وما تبقى لتحقيقه. أن يكون الفرد مسئول مسئولية ذاتية عن صياغة أهدافه والسعى لها. 
( (Chase Nordengren, 2019, p 19) (

( $V): 9 r$

ومن أهم الأهداف التى يمكن توجيه الفرد إليها ، هى الأهداف النى تثكل حافز نحو

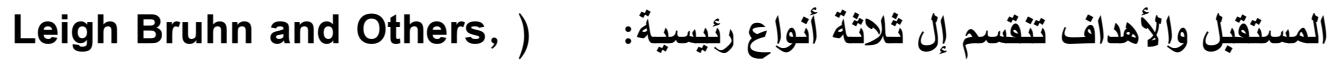

2017. pp. 66:73

( ) أهداف وقتية: وتنقسم إلى قصيرة المدى ، ويعيدة الددى وهى مسئولة عن قرارات الفرد. r أهداف مركزية: وهو ما يطمح إليه الفرد فى العمل والحياة.

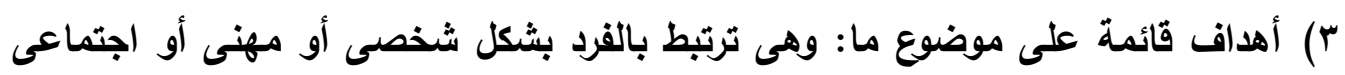
وتتطلب منه جها لفترة ما.

وجميع أنواع الأهداف هامة ومرتبطة بحياة المتعلم مما يتطلب من المطلم توجيهه

إليها والعمل على تحقيقها وفقاً لإمكانياته الخاصة.

وقد تعددت الأهداف التى يسعى الأفراد إلى تحقيقها وإعطاء قيمة للهاف وترتئي

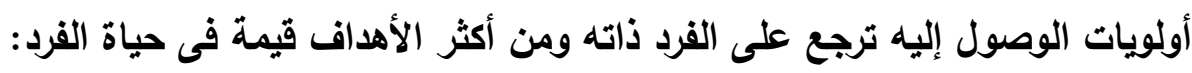
البحث عن التعليم والعمل التى يفضل القيام به.

الإهتمام بالذات وتحقيقها.

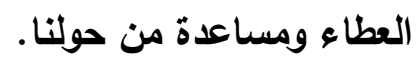

الإستمتاع بالحياة والثعور بالإستقرار والأمان.

توطيد العلاقات الإجتماعيه الناجحة مع الآخرين.

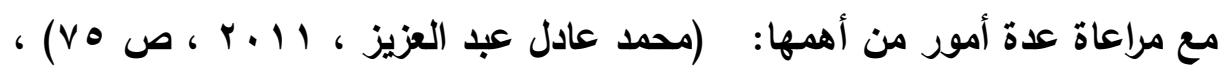

Heather Gross, 2019, p. 106 )

ترتيب الأهداف وفقاً للأولويات.

تحديد نطاق العمل لتحقيق هدف واحد أو مجموعة أهداف.

صياغة الهذف العام والأهداف الفعلية المرتبطة به.

إعداد جدول زمنى لإنجاز الأهداف وفقاً لترتيب أولوياتها.

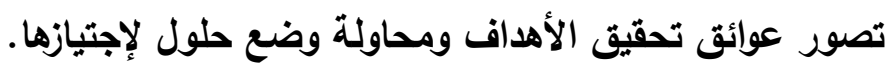

خلق بيئة العمل المناسبة لتحقيق الأهداف. 
كتابة الأهداف حتى يمكن الاحتفاظ بها من الفقد. متابعة التقدم والإنجاز. ولتحقيق الأهداف المرغوية على المعلم أن يساعد طلابه على التمكن من مجموعة

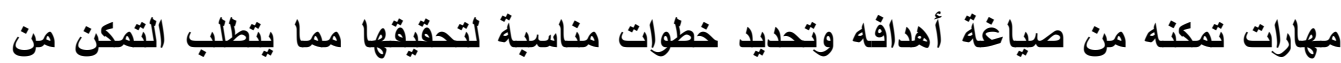
عدة مهارات من بينها: (Allison Bruhn and Others, 2016, pp 107:121) ربط الخبرات السابقة بالخبرات الجديدة. فهم الذات والغايات التى يمكن تحقيقها ورسم خطط مستقبلية. إدراك ما وراء الأفعال. ترتيب العمل وفق أولويات واضحة ومحددة. تحديد الأهداف العياتية والمستقبلية والسعى لتحقيقها. وقد تعددت الدراسات التى أكلد على أهمية تمكن المتعلم من مهارات التوجه نحو أهدافه فى مراحل عمرية مبكرة مما يمكنه من رسم الطريق إلى مستقبله بفعاليه وتحديد حجم

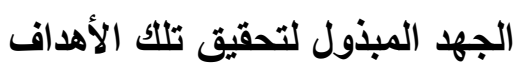
وأيضاً يولد لايه الدافع للعمل والنجاح. ومن بين تلك الدراسات:

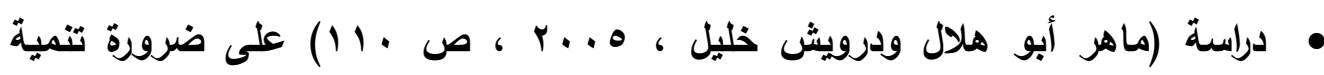

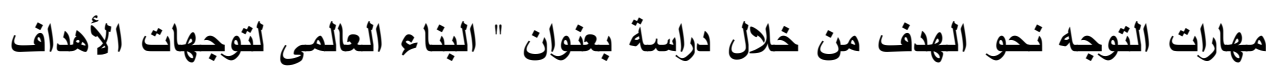

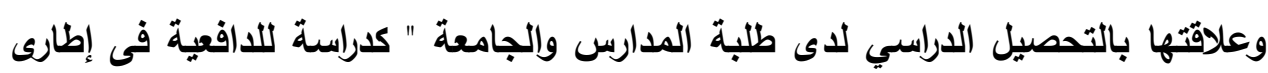

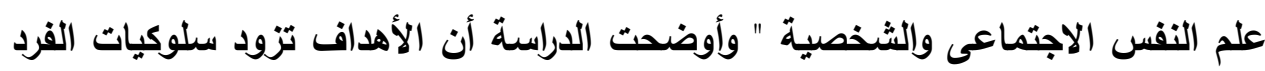
بالمعنى والإنسجام وتهيئ المسرح لكل المكونات الآخرى كى تعمل بشكل هادف ومتناغم. ودراسة (Serverine Erthel, 2016, p. 1744) حيث أجريت دراسة على توظيف الألعاب الرقمية فى بيئات التعلم التفاعلية من خلال التعليمات الموجهة نحو الهدف وقد تضمنت نوعان من المهارات (إتقان الهاف ، إرشادات الهدف) لتشجع المتعلمين على هلى إثبات قدراتهم على النجاح وقد أسفرت الدراسة على أهمية توظيف التعليمات الموجهة نحو الهذف لتعزيز نشاط المتعلم

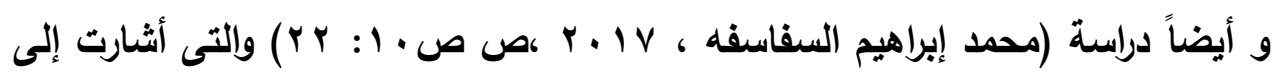

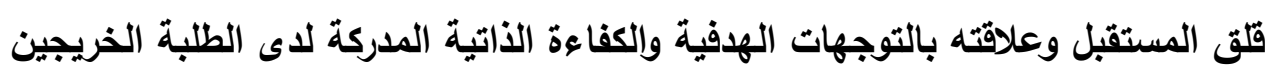


فى جامعة مؤتة وأوضحت الداسة بأنه حتى يكون الفرد قادراً على تحقيق أهدافه ومواجهة المشاعر السلبية كالقلق، عليه ان يتصف بالكفاءة الذاتية التى تحفزه للإنجاز وإنه على المعلم عبئ كبير فى تحقق تلك الكفاعة لاى المتعلمين.

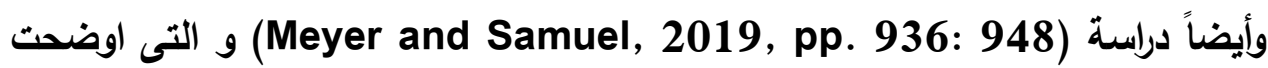
قيمة العلاقات كهذف للتعليم وان التعليم من شأنه توجيه المتعلمين لتنمية قدراتهم التى تكتشف فى علاقات الحياة اليومية مما ينعكس على تطوير الكفاعة فى المعرفة والعمل

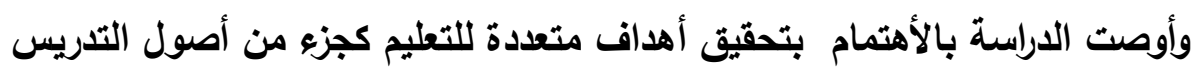

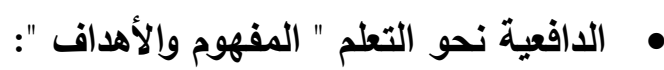
إن الهذف الأعظم من مهارات التدريس هو إثارة دافعية المعلم نحو التعلم وعلى ذلك

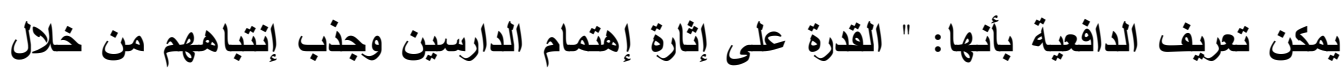

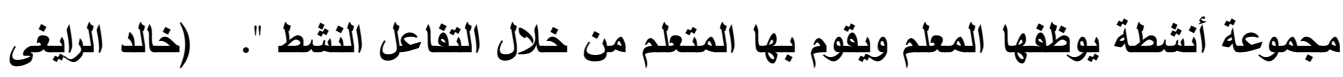

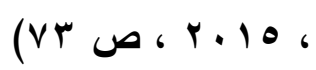

وفى تعريف آخر " الدافعية هى حالة داخلية توجه نشاط الفرد حول هدف ما فى ، هالي

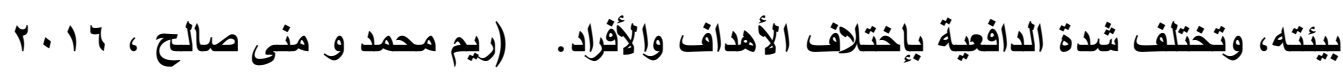

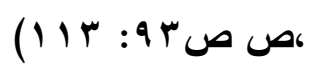

ومما سبق يتضح إن الدوافع هى محركات داخلية موجودة لدى جميع المتعلمين

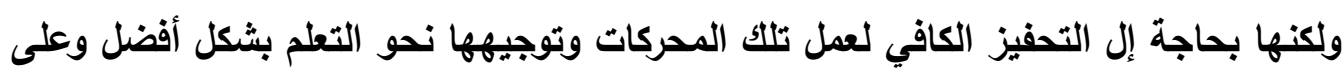

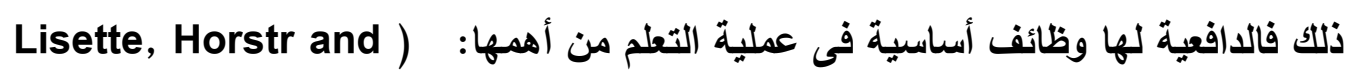
(Others, 2018, pp. 1:18 الوظيفة الإستثارية: فالدوافع تثير الفرد للقيام بسلوك ما ، وهناك علاقة قوية بين درجة الإستثارة وقوة توجه السلوك. الوظيفة التوقعية للاوافع: فالإعتقاد هو حكم مؤقت بأداء سلوك ما وقد تتحقق النتائج المتوقعة أو لا تتحقق وفقاً لارجة الدافعية. الوظيفة الانتقائية: حيث يوجه السلوك نحو مثير معد له مسبقاً. الوظيفة التوجيهيه: حيث توجه الطاقة نحو سلوك محدد مسبقاً. 
الوظيفة الباعثة للاوافع: من حيث توظيف أساليب الثواب والعقاب كأساليب باعثة للاوافع

الكامنة.

وعلى المعلم دور هام فى تتمية الدافعية لاى طلابه من خلال توظيف أساليب

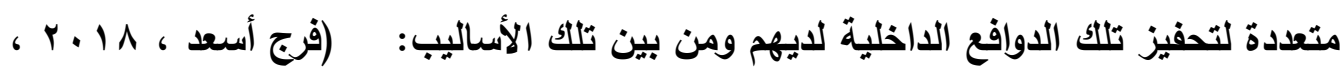

ص ص • ( • توظيف الأمثلة للطلاب عن الأشخاص القدوة الذين وصلوا إلى المجد والتميز من خلال التعلم والإجتهاد.

رفع مستويات الطلاب التعليمية من خلال مقارنته بذاته ومدى التحسن فى قدراته. إستبدال الأفكار السلبية عن التعلم بأفكار إيجابية. الفهم الصحيح لقدرات المتعلم نقاط القوة لايه. وضع خطط للعمل مما يساعده على تنظيم أولوياته.

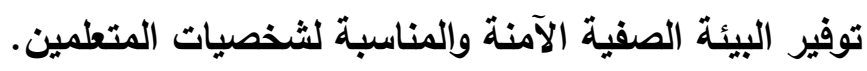
بث روح التحدى لاى الطلاب للنجاح والتميز. إستخدام التعزيز بأشكاله المختلفة لدعم السلوك الإيجابى والتوجه نحو العمل بحماس وجهد.

وللدافعية عدة مكونات من أهمها: اجل

$$
\text { - } \begin{array}{r}
\text { - الطموح الأتى } \\
\text { - }
\end{array}
$$

كما حدد (Maximillia and Franz, 2016) مكونات الدافعية بأنها: *الرغبة المستمرة فح إنجاز العمل. التفانى فى العمل.

$$
\begin{aligned}
& \text { * الرغبة فى تحقيق الذات. } \\
& \text { "التفوق والطموح. }
\end{aligned}
$$

كما أكدت بعض الدراسات ان هناك علاقة بين الدافعية وتوجيه السلوك وأداء الفرد

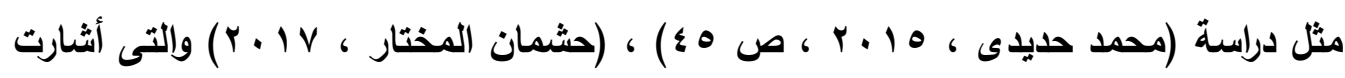
إلى العلاقة بين إثارة الاففية وإرتفاع مستوى أداء الفرد من خلال توظيف التعزيزات المختلفة، فكلما كان التعزيز قوى أرتفع مستوى الادفية والأداء معاً، ويحدث ذلك من خلال 
إزالة حالة التوتر والقلق ، وتوظيف إستراتيجيات وطرق ناجحة وتقديم الفرص للمشاركة فى تحديد الأهداف.

وللمعلم أهمية بالغة فى العملية التعليمية فهو الوسيلة الأساسية لنقل العلم إلى عقل

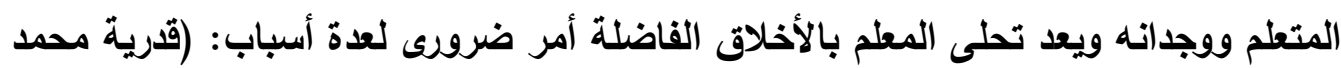

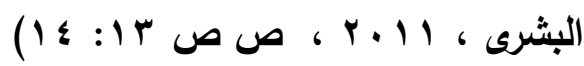
لا يمكن تصور المعلم بدون أخلاق.

ها يمكن بناء علاقات تريوية سليمة بين المعلم وطلابه بدون قاعدة أخلاقية يستند عليها. ومن أهم تلك الجوانب الأخلاقية التى يجب ان يتحلى بها المعلم (الإخلاص فى ، والثي

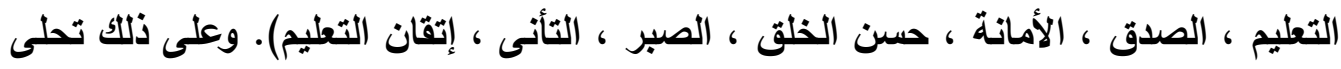

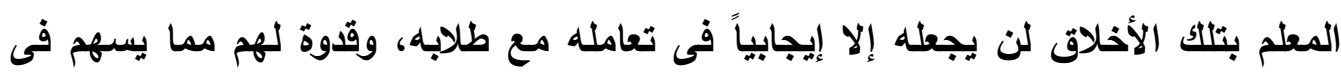
علاقات تريوية سليمة داخل المؤسسات التعليمية. والمعلم الناجح هو من يستطيع التعامل مع الطلاب بثكل صحيح وهو الأى يعطى ردود فعل جيدة حول كل ما يقوم به طلابه من خلال تثجيعهم بردود فعل لفظية وإرشادهم ودفعهم

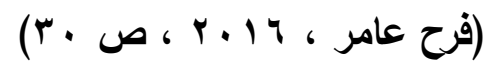
بشكل مناسب لتطوير أفكارهم. وعلى ذلك فإن إنخراط المعلم مع طلابه داخل حجرة الاراسة هذا إلى جاتب تطوير قدراتهم

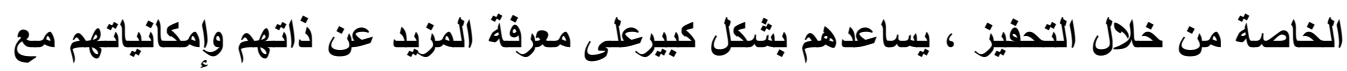

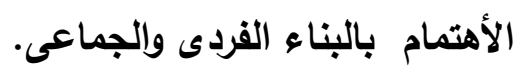

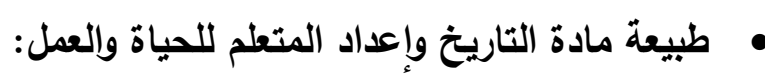
التاريخ هو أحد فروع العلم الذى يدرس السجل الزمنى للأحداث التى أثرت على أمه أله

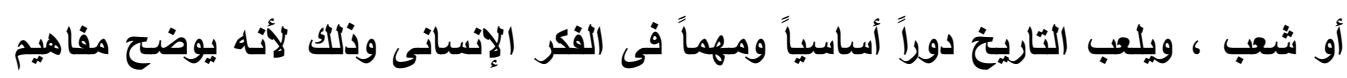
التغير والظروف المادية التى تؤثر على الثئون الإنسانية.

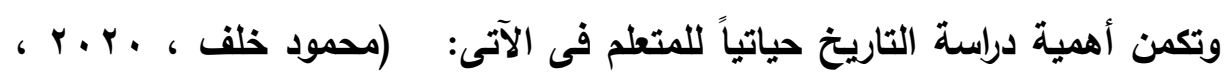

$$
\text { ص ص } 9 \text { ( IV }
$$

يساعد فى معرفة شأن الأمم والطريق التى تقدم بها الإنسان.

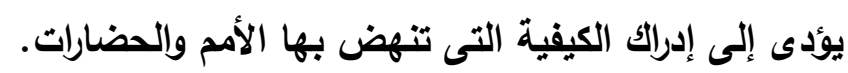


يعلم التاريخ ما ينفع الإنسان من أجل استدامة النوع والأفكار والعلوم والحضارة. يقلم نماذج حية للنجاح حيث يرى الإنسان فيها الإيجابية مما يشكل دافع للعمل والإنجاز .

وعلى المناهج الدراسية بصفة عامة والتاريخ بصفة خاصة إعداد المتعلم للحياة

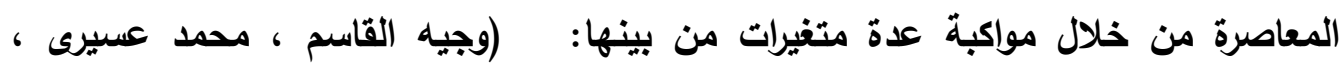

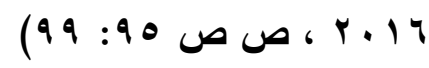
الإنجازات العلمية الحديثة وإلمستحدثات التكنولوجية. إحتياجات المجتمع ومعالجة السلوكيات غير السوية. النتاجات التعليمية التى يسعى التعليم إلى تحقيقها لمواكبة التطورات المعاصرة. ونظراً للتغيرات العالمية المعاصرة، تحتاج التربية إلى إعداد متعلم قادر على إستيعاب إبهاب

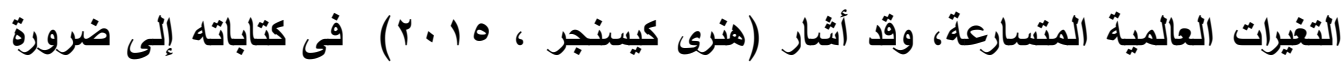

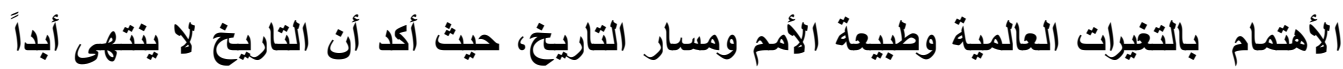
وأن الواجب على الشعوب إستيعاب دروس الماضى والبحث عن نقاط التحول التاريخية وضرورة تحليل طبائع الأمم والثقافات الرئيسية فى العالم. وطلاب المرحلة الثانوية هم طلاب فى مرحلة المراهقة العمرية حيث يظهر عليهم

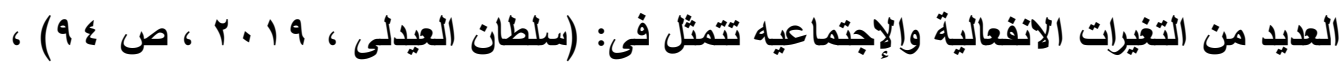

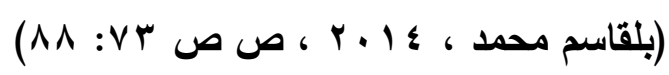
تطور المشاعر والحساسية الانفعالية. الرغبة فى الإستقلالية والاعتماد على الذات. ثقل العلاقات الإجتماعيه ويلورة المقربين إليه. البحث المستمر عن القدوة والنموذج. الحساسية للنقا والميل نحو الجدل الهادف. نمو الشعور بالمسئولية الإجتماعيه. الإهتمام بالذات وتقدير النفس.

وعندما كان الدافع هو المحرك الأساسى للسلوك البشرى ، فطالب المرحلة الثانوية بكل ما يمتلكه من سمات وخصائص وتغيرات نفسية وبيولوجية أكثر حاجة لتلك الدوافع التى 
توجهه إلى الإختيارات الصحيحة ، وإرتفاع الدافعية بصفة عامة يسهم فى تحقيق نجاحات

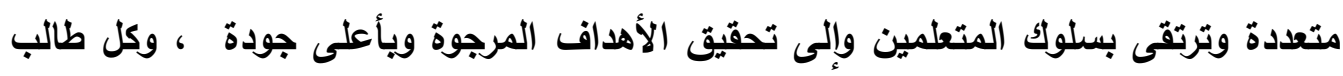

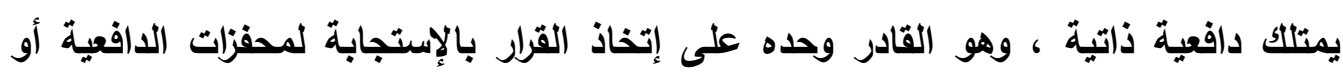

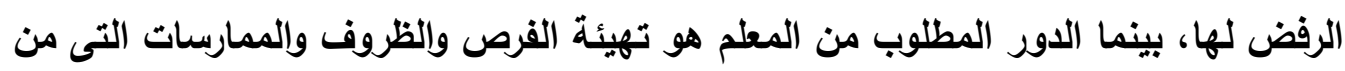

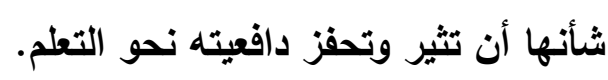

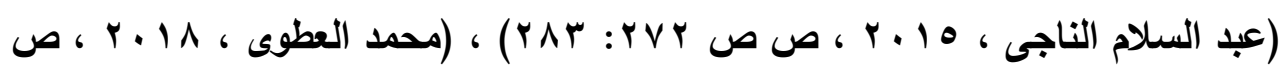

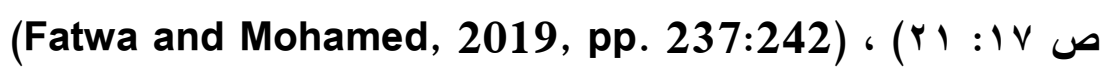
و من العرض السابق يتضح أهميه خلق التحفيز الكافي من المعلم للمتعلم، مما

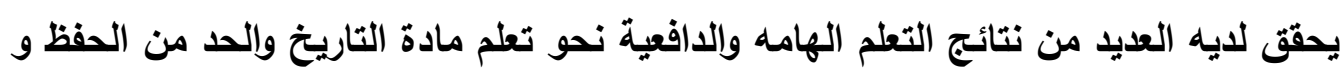
الإسترجاع و العمل على توظيف التعلم حياتياً وعملياً.

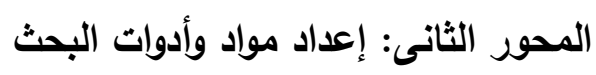

يشتمل هذا المحور على عرض مواد البحث المتمثلة فى إعداد قائمتين هما (قائمة مهارت التوجه نحو الهذف و قائمة بأبعاد الدافعية للتعلم) لتوجيهها إلى طلاب المرحلة

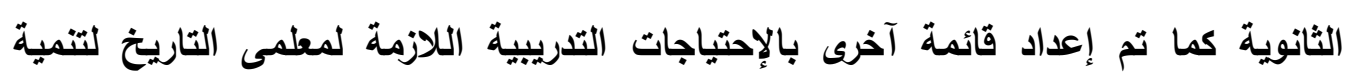
الكفاءات المهنيه لايهم، والتى تمكنهم من أداء مهامهم بنجاح مع طلابهم ثم تم تدريب إنهات المعلم على إستثارة طلابهم للتعلم وتوجيه دافعيتهم من خلال برنامج معد فى ضوء التهاء التعلم

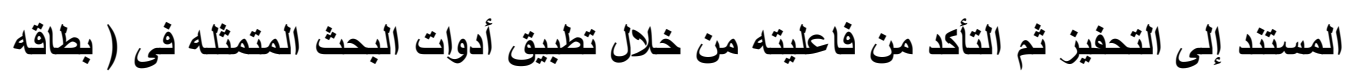

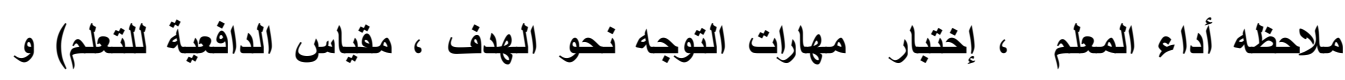

تفسير النتائج و مناقشتها.

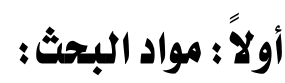
اشتملت مواد البحث على

1- إعداد قائمة مهارات التوجه نحو الهدف المناسبة لطلاب المرحلة الثانوية (الصف الأول الثانوي) والتى يمكن تنميتها لايهم من خلال تدريس مقرر التاريخ وذلك من خلال إعداد

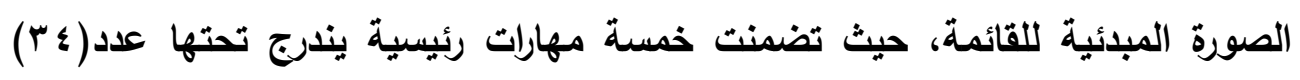
مهارة فرعية وقد تم ضبط القائمه من خلال عرضها على مجموعة من السادة المحكمين 
تخصص مناهج وطرق تدريس تاريخ و دراسات إجتماعيه، للتأكد من صدق القائمة

$$
\text { وصلاحيتها من حيث 1": }
$$

( ) مدى مناسبة المهارات الأساسية والفرعية لطلاب المرحلة الثانوية. r) مدى إرتباط المهارات بواقع المتعلم وحياته بحيث تفيده فى تحديد أهدافه التعليمية والحياتية.

r) مدى إرتباط المهارات بتنمية الدافعلية للتعلم لاى الطلاب. وفى ضوء آراء المحكمين تم وضع القائمة فى صورتها النهائية لتتضمن المهارات

الآتية:

( ) إستثمار المعرفة السابقة لبناء الخبرات الجديدة.

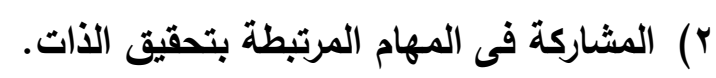
r) إدرالك ما وراء التصرفات. ؛) العمل وفق أولويات.

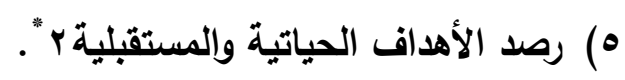
و بذلك يكون قد تم الإجابه على السؤال الأول للبحث " ما مهارات التوجه نحو

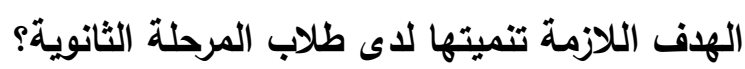

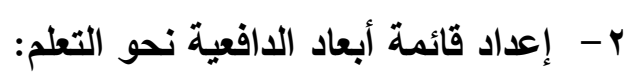

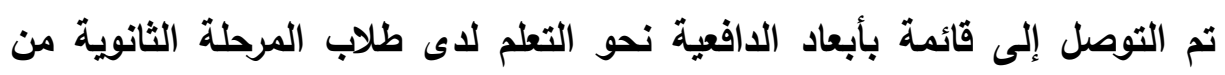

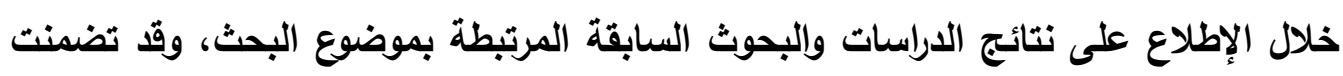

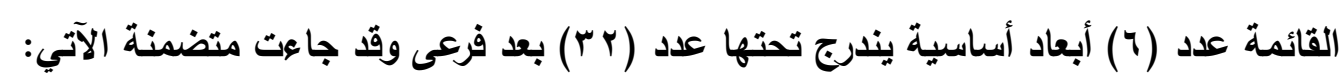
( ) الدم الرغبة فى التعلم.

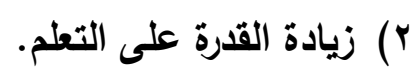
ب) توجيه الجهر لتحقيق الأهداف التعليمية. ؛) السعى الأتي للتطوير فى التعلم. •) إطلاق الطاقات الكامنة والقدرات الخاصة. 
7) توفير الظروف المشجعة على التعلم بفعالية.

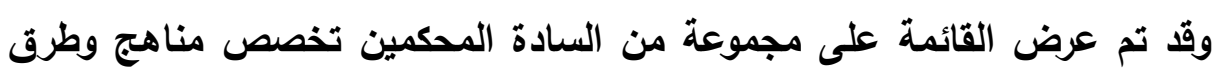
تدريس للتحقق من: أ) دقة الصياغة اللغوية وملاءمتها. ب) صحة مدلول كل بعد من الأبعاد الفرعية.

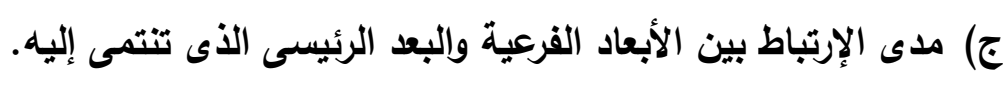
د) إضافة أى أبعاد آخرى يروا مناسبتها للبعد الرئيسى.

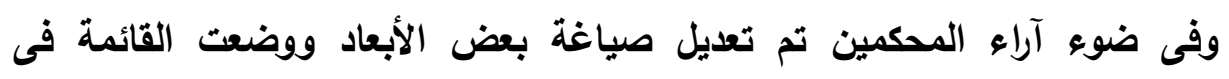

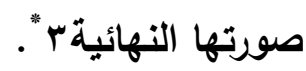
ويذلك يكون قد تم الإجابه على السؤال الثانى للبحث " ما أبعاد الاففعية نحو التعلم اللازم تنميتها لاى طلاب المرحلة الثانوية ؟ r- إعداد قائمة بالإحتياجات التدريبية اللازمة لمعلمى التاريخ لتنمية الكفاعات المهنيه لديهر حيث تضمنت القائمة عدد ستة مجالات رئيسية يجب على المعلم التمكن منها وهى: المجال الأول: تحديد الأهداف بشكل واضح. المجال الثانى: إثارة إستعداد المتعلم لعملية التعلم. المجال الثالث: إختيار نوع النشاط الذى يحفز المتعلم على الأداء الناجح. • المجال الرابع: توظيف طرائق بسيطة وناجحة تمكن المتعلم من التعلم بفاعلية. هالمجال الخامس: تدريب المتعلم على تحمل المسئولية الذاتية لتحقيق الأهداف المرجوة. المجال السادس: رفع مستويات الطلاب التعليمية من خلال دعم دافعيتهم للتعلم.

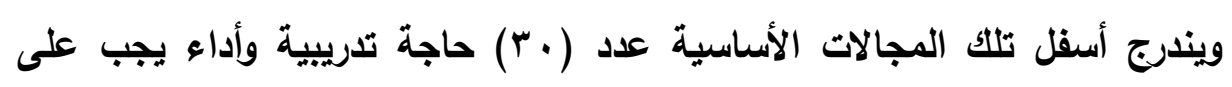
المعلم التمكن منها لتحفيز طلابه للتعلم. وقد تم عرض القائمة عل مجموعة من السادة المحكمين لضبطها فى ضوء النقاط التالية: مدى وضوح ودقة الأداءات المتضمنة بالقائمة. مدى الحاجة إلى التمكن من تلك الأبعاد من حيث مستويات محددة تتدرج من شديدة جداً إلى ضعيفه جداً. 
مدى ملاعمة الأداعات المتضمنة بالقائمة للاحتياجات التدريسية. إبداء ملاحظات عامة عن القائمة ككل.

تقايم مقترحات بالإضافة أوالحذف والتى تزيل من موضوعية القائمة.

وفى ضوء آراء المحكمين تم وضع قائمة الإحتياجات التدريبية فى صورتها النهائية ؛ ؛". و بذلك يكون قد تم الإجابه على السؤال الثالث للبحث " ما الإحتياجات التدريبيه اللازمده

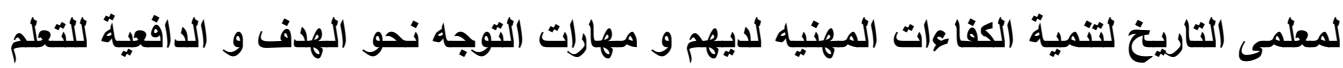
لادى طلابهم? ع - إعداد البرنامج التدريبى لمعلمى التاريخ القائم على التعلم المستتد إلى التحفيز : وقد إستفادت الباحثة من نتائج البحوث والدراسات السابقة من حيث كيفية بناء البرامج التدريبية من حيث الأساليب والأنماط المستخدمة فى إعداد المعلمين قبل وأثناء الخدمة ومن بين تلك الدراسات: دراسة مقارنة فى الولايات المتحدة وتركيا (Hidri Karaduman, 2017) حول آراء المرشحين للاراسات الإجتماعيه حول المواطنة الرقمية ومكانتها فى برامج تدريب المعلمين

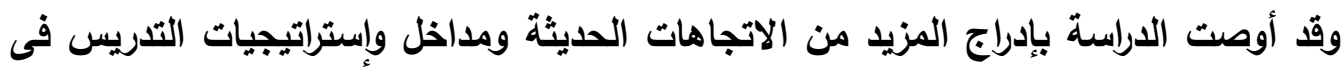
برامج تدريب معلمى الدراسات الإجتماعيه. دراسة (Bustos and Alejanro, 2019) والتى أكدت على أهمية تطبيق برامج

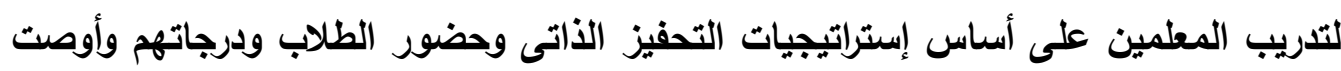
بتطبيق برامج لتدريب المعلمين أثناء الخدمة. وكذلك دراسة (Mardapi and Others, 2019) وقد أظهرث النتائج إن تدريب المعلمين على المستوى المحلى بإندونيسيا كان بمثابة تحول فى استراتيجية تطوير المعلمين وزيادة الاحتراف المهنى. و أيضاً أشارت دراسة (Victoria and Others, 2020) إلى أهمية تقديم تصورات المعلمين حول التّريب الذى يتلقونه فى التعليم بين الثقافات وأظهرت النتائج أنه رغم نقاط القوة لا يزال تدريب المعلمين يمثل تحدياً متمثل فى نقاط الضعف مثل (عدم المرونة ، أولوية التعليم النظرى).

" ملحق رقم (؛ ) قائمة الإحتياجات التدريبية لمعلمى التاريخ لتنمية الكفاعات التدريسيه لديهم. 
كما أكلت (Pramesti and Others, 2020) من خلال دراسة لهم على أن إدارة

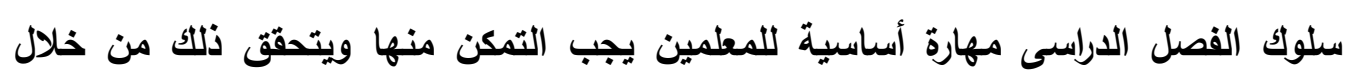

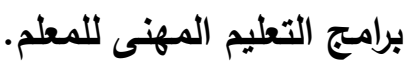

ومن المعروف إن أى برنامج تدريبى له مكوناته وعناصره الأساسية التى يشتمل

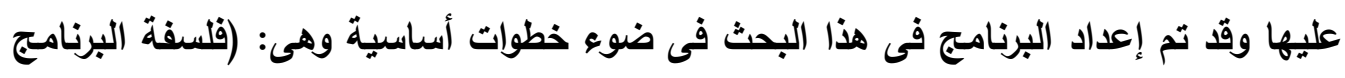

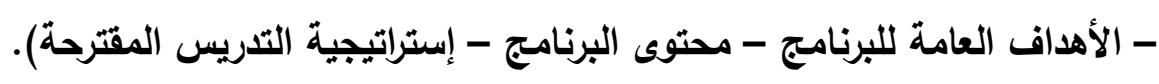

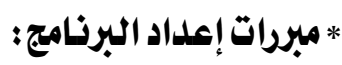
استناداً إلى الحاجة لتحسين أداء المعلم أثناء الذدمة حدثت الباحثة المبرات التالية

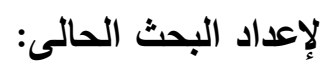

1) الإرتقاء بمستوى أداء المعلم حيث يكتسب المعلم قدرات جديدة ومهارات تدريسية تمكنه

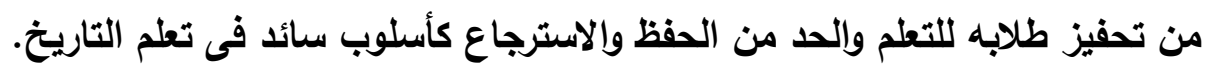

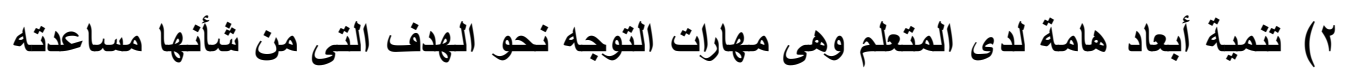

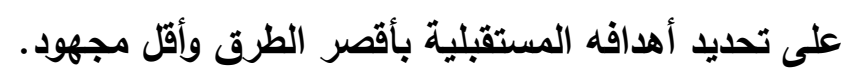

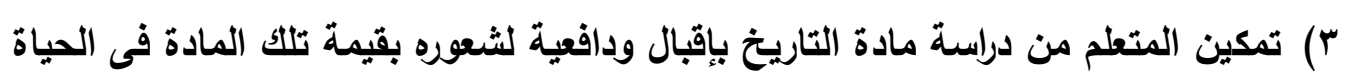
وانعكاس ذلك على قراراته الحياتية.

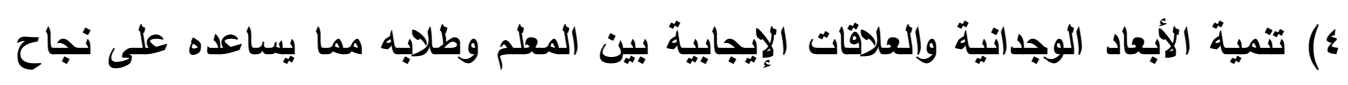
عملية التعليم ويقاء أثر التعلم.

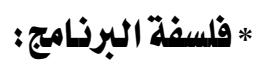
يعتمد البرنامج على إستخدم أنماط وطرق متعددة فى التدريس مثل (الحوار والمناقثة -

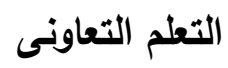
- العصف الأهنى - القبعات السته للتفكير - جدول التعلم ).

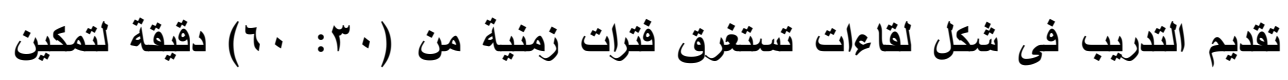
المعلمين من أساليب تحفيز طلابهم للتعلم وتنمية المهارات و الدافعية للتعلم لديهم.

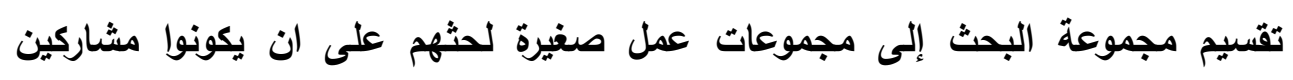
ونشطين أثناء التعلم وممارسة الأنثطة. كما يستتد البرنامج على عدد من الأسس وهى: 
الإعتماد على قائمة الكفاءات التدريسية (الإحتياجات التدريبية) التى تمكن المعلم من

أداء عمله بنجاح.

صياغة الأهداف فى شكل عبارات سلوكية واضحة. هالتركيز على إيجابية المتعلم وتفاعله مع المعلم أثناء تطبيق البرنامجه.

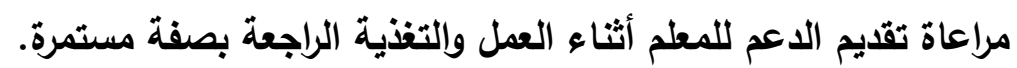

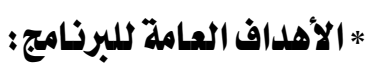

يردف البرنامج التريبى المستتد إلى التحفيز على تحقيق الآتى: ( ) تنمية مهارات التوجه نحو الهدف لاى طلاب المرحلة الثانوية. r) تنمية الدافعية للتعلم لاى الطلاب من خلال دراسة مادة التاريخ.

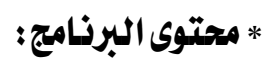
تم إختيار محتوى البرنامج وفقاً لعدة أسس:

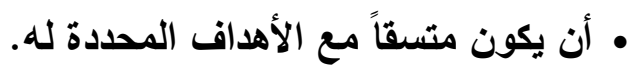
• أن يكون قابل للتطبيق والتتفيذ. • أن يكون مشوقاً للمتعلم وأن يحفز لايه التفكير والعمل. • أن يحقق نمو الكفايات المهنية اللازمة للمعلم لتحفيز طلابه لتحديد أهدافهم من التعليم. وقد تتضمن عرض المحتوى (عنوان الدرس- الفترة الزمنية - المهارات المراد

تنميتها لاى المتعلم - الأهداف الإجرائية - موضوعات الدرس - التوريبات - الأنثطة - الأنشئ إستراتيجيات (التدريس)

وقد راعت الباحثه عند إعداد موضوعات البرنامج ما يلي: • وضوح أهداف كل موضوع وصياغتها سلوكياً بحيث توضح ما يراد تحقيقه من دراسة الموضوع. • تنوع الخبرات التي يشتمل عليها البرنامج. • إرتباط المحتوى بطبيعة مادة التاريخ وأهداف تدريسها في المرحلة الثانوية. 
* أساليب تدريس البرنامج:

$$
\text { تم الإعتماد على الأساليب التالية في التدريس: }
$$

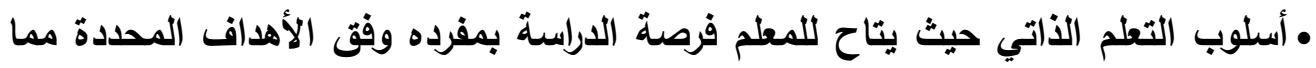
يتيح للمتعلم معرفة نقاط القوة والضعف لايه وتحسين الأداء.

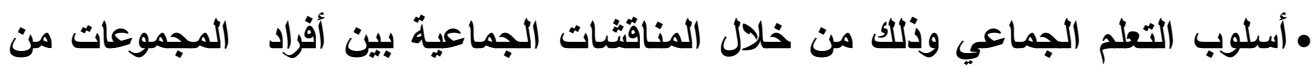
المعلمين مما يساعد على تبادل الخبرات وتثبيث المعلومات وتصحيح المسار أثناء العمل الجماعي.

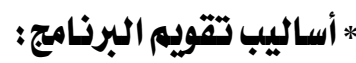
يعد التقويم من الجوانب الأساسية في التدريب حيث تقف على مستوى أداء المعلم والتدريس من حيث الإتقان ومدى التقدم ليصبح أداءه مقبولاً في البرنامج ، وقد تم تقويم

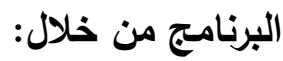
- التدريب في نهاية كل موضوع للوقوف على مدى تحقق الأهداف المتضمنة لكل موضوع مع الحرص على تقديم التغذية الراجعة.

- بطاقه ملاحظه المعلم لقياس الجانب الأدائي بعد الانتهاء من دراسة البرنامج هـ (1) -

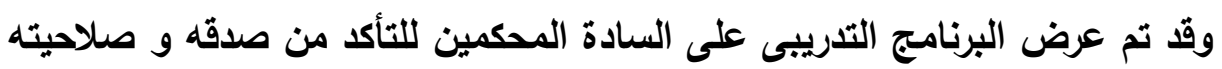

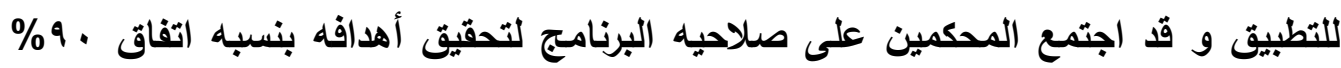
من إجمالى الاراء. ويذلك يكون قد تم الإجابه على السؤال الرابع للبحث: ما موره برنامج تدريبى لمعلمى التاريخ قائم على التعلم المستند للتحفيز لطلاب المرحلة الثانوية ؟ ثانياً : إعداد أدوات البحث : 1

للتحقق من إرتفاع مستوى أداء المعلم في الكفاءات المهنية التلازمة لتنمية مهارات التوجه نحو الهذف لاى طلابه وزيادة دافعيتهم نحو التعلم من خلال التمكن من تحفيز الطلاب، تم تصميم بطاقة ملاحظه يعتمد تطبيقها على أسلوب الملاحظة المباشرة للسلوك الأي يقوم به المعلم و يوظقه من خلال التدريس للطلاب وقد تم إعداد البطاقة في ضوء: 
• مراجعة الأدبيات والدراسات السابقة والتي ركزت على سلوك المعلم وأدائه الوظيفي

• أهداف تدريس التاريخ للمرحلة الثانوية وقد تم تحديد ثلاثة أبعاد اساسية للكفاءات

المهنية للمعلم وهي:

م الكفاءات المعرفية.

م الكفاعات الشخصية.

م الكفاعات التدريسية.

وقد تم تحديد مستويات أداء فرعيه لكل كفاية من الكفاءات المهنية الأساسية وقد تم تقدير الأداء من خلال ثثلاثة بدائل (درجة عالية - درجة متوسطة - درجة ضعيفة) وقات

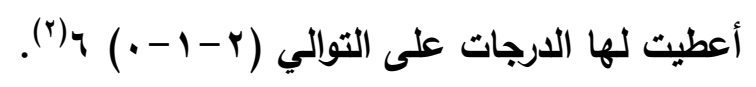

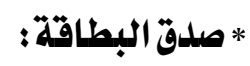

تم التحقق من صدق البطاقة من خلال عرضها على مجموعة من المحكمين المتخصصين في مجال المناهج وطرق التدريس للوقوف على مدى الاتفاق في العناصر التالية:

• الشكل العام لبطاقة الملاحظة.

• ما تتضمنه من كفاعات أساسية وفرعية من حيث المسمى والعدد. • مدى الإرتباط بين الكفاعات الأساسية والفرعية التي تنتمي إليها. • مدى مناسبة صياغة المفردات اللغوية للعرض والتطبيق.

وقد تم إعداد بعض التعديلات البسيطة في صياغة بعض المهارات الفرعية وقد وصلت نسبة الاتفاق على صلاحية البطاقة للتطبيق (r 9\%) بعد إبداء الرأي والملاحظات

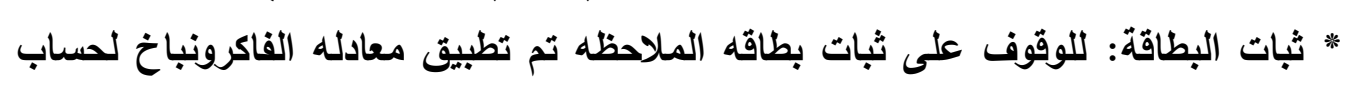
الثبات على النحو التالى: تلبات 


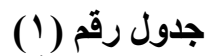

ثبات بطاقه ملاحظه أداء المعلم

\begin{tabular}{|c|c|}
\hline الفاكرونباخ & بطاقه ملاحظه أداء المعلم \\
\hline$* * \cdot, \mathrm{VH}$ & كفاءات معرفية \\
\hline$* *,, V Y$ & كفاءات شخصية \\
\hline$* *,, \vee q$ & كفاءات تدريسية \\
\hline$* *,, \vee 0$ & البطاقه ككل \\
\hline
\end{tabular}

* * تثير إلى مستوى دلالة ه•,,

يتضح من الجدول السابق ان جميع معاملات الإرتباط بالدرجة الكلية لبطاقة ملاحظة

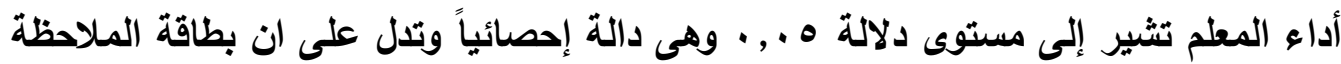
تتمتع بالثبات.

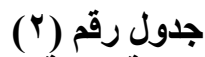

معامل إرتباط الكفايات بالارجة الكلية لبطاقة ملاحظة أداء المعلم

\begin{tabular}{|c|c|}
\hline معامل إرتباط المحور بالارجة الكلية للبطاقة & بطاقه ملاحظه أداء المعلم \\
\hline$* *, 9 \varepsilon$ & كفاعات معرفية \\
\hline$* * \cdot, 0 \wedge$ & كفاعات شخصية \\
\hline$* *, \leqslant 1$ & كفاءات تدريسية \\
\hline
\end{tabular}

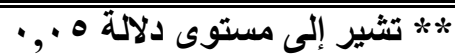

يتضح من الجدول السابق أن جميع معاملات إرتباط الأبعاد بالارجة الكلية ببطاقه

ملاحظه أداء المعلم تثير إلى مستوى دلالة ه ه. , · وهى تدل على وجود الإرتباط.

r - إختبار مهارات التوجه نحو الهدف

\section{• الهدف من الإختبار}

هدف الاختبار إلى قياس ما لدى طلاب المرحلة الثانوية من مهارات عقلية و ادائيه تمكنهم من تحديد أهدافهم (الاتية والحياتية والمعرفية) بصدق مما ترتب عليه تحقيق نجاحات وتقدم، وقد تم إعداد الاختبار في شكل مواقف اجتماعية وحياته لقياس قدرة الطلاب (مجموعة البحث) على تحديد تلك الأهداف المطلوبة لايهم.

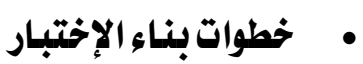

تم إعداد الإختبار التحصيلى في شكل مواقف بلغ عددها (·r) موقف موزعه على النحو

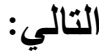




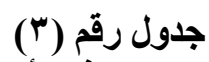

توزيع اسئله الاختبار وفقا لأهداف المتعلمين

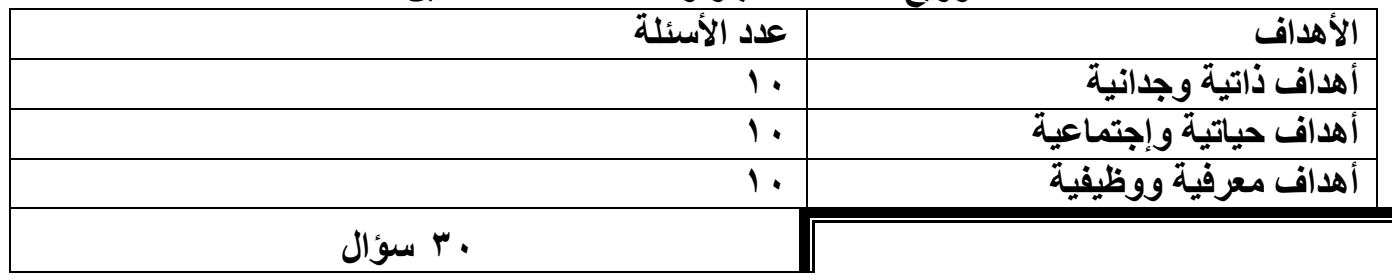

وقد تم تصميم الموقف في شكل عبارة يندرج تحتها أريعة بدائل تعبر عن توجهات أهداف الطلاب نحو هذا الموقف وعلى الطالب إختيار أحد البدائل

وقد تم مراعاة الآتي عند صباغة المواقف: - أن تكون المواقف حياتية تمس حياة المتعلم ومستقبله. - أن تكون مناسبة لمستوى الطلاب. - أن تكون واضحة الصيغة وإلمعنى. - إعداد جدول مواصفات الاختبار لتحديد المهارات التي يجب أن يتمكن منها المتعلم للتمكن من إختيار أهدافه الصحيحه و التوجه إليها.

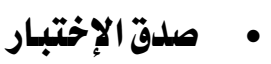
تم عرض الاختبار على مجموعة من المحكمين وقد جاعت نسبة إتفاق المحكمين على مناسبة الاختبار من حيث الاعداد واللهدف من توظيفه ومناسبه المفردات والصياغة

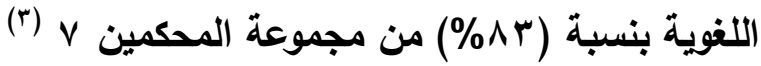

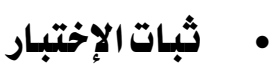
تم تقديم ثبات الاختبار بطريقة إعاده تطبيق الاختبار على مجموعة البحث بفاصل زمني أسبوعين وتم حساب معامل الإرتباط بين التطبيق الأول والثاني عن طريق معادله بيرسون لحساب معامل الثبات وقياس مدى الاتساق الاخلي وقا جاءت نسبه الثبات $\cdot(\% \wedge \varepsilon)$ كما تم تطبيق معادله الفاكرونباخ لحساب ثبات الاختبار و قد جاءت النتائج على

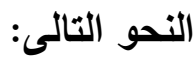




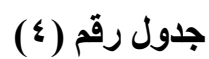

ثبات إختبار مهارات التوجه نحو الأهداف

\begin{tabular}{|c|c|}
\hline الفاكرونباخ & مهارات التوجه نحو الأهداف \\
\hline$* *, \wedge \theta$ & أهداف ذاتية - وجدانية \\
\hline$* *, \vee 1$ & أهداف حياتية ـاجتماعية \\
\hline$* * \cdot, V \mu$ & أهداف معرفية _وظيفية \\
\hline$* *, \wedge 1$ & المهارات ككل \\
\hline
\end{tabular}

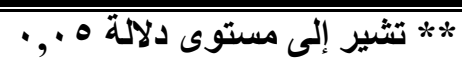

يتضح من الجدول السابق ان جميع معاملات الإرتباط بالارجة لمهارات التوجه نحو الأهداف تثير إلى مستوى دلالة ه. ., . وهى دالة إحصائياً وتدل على ان مقياس مهاريات بالهات التوجه نحو الأهداف يتميز بالثبات.

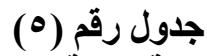

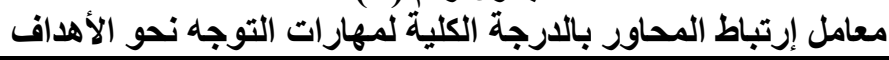

\begin{tabular}{|c|c|}
\hline محو الأهداف إنباط المحور بالدرجة الكلية لمهارات التوجه & مهارات التوجه نحو الأهداف \\
\hline$* *, 00$ & أهداف ذاتية ـ وجدانية \\
\hline$* *, 7$ & أهداف حياتية _اجتماعية \\
\hline$* *, \leqslant \psi$ & أهداف معرفية _وظيفية \\
\hline
\end{tabular}

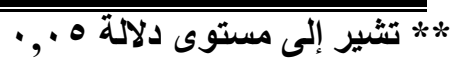

يتضح من الجدول السابق أن جميع معاملات إرتباط الأبعاد بالدرجة الكلية لمقياس

مهارات التوجه نحو الأهداف تثير إلى مستوى دلالة ه ه. , · وهى تدل على وجود الإرتباط.

• تصحيح الاختبار

تم إعطاء استجابات تناسب عبارات الإختبار بحيث تمثل الإستجابة الصحيحة للموقف الارجة (r) وتقل كلما ابتعدت الإجابة الصحيحة عن التمكن من مهارات التوجه نحو الهـف وقد تم حساب معاملات السهولة والصعوية للإختبار من خلال المعادلة التالية :

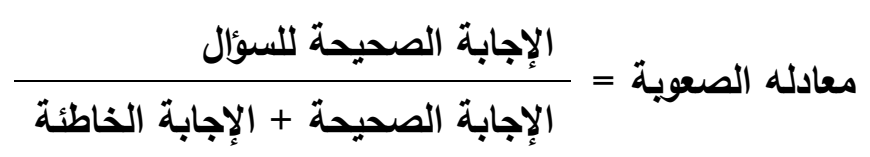

r - مقياس الدافية للتعلم بعد الإطلاع على الإدبيات والدراسات السابقة المرتبطه بمشكلة البحث تم إعداد مقياس الدافعية للتعلم لطلاب المرحلة الثانوية وفق الخطوات التالية: 
- - تحديد الأبعاد الرئيسية للمقياس.

- - - مياغة الفقرات التي تتدرج أسفل كل بعد من الأبعاد الرئيسية.

- مراعاة إرتباط الأبعاد الفرعية للفقرات بالأبعاد الرئيسية.

- مراعاة الصياغة اللغوية المناسبة لفهم مضمون الفقرات بالنسبة لمستوى متعلمي

المرحلة الثانوية.

• صدق المقياس وضبطته

للوقوف على مدى صدق المقياس تم عرضه على مجموعة من المحكمين لإبداء الرأي والملاحظات وقد تم إجراء بعض التعديلات البسيطة للمقياس من خلال الحذف والإضافة

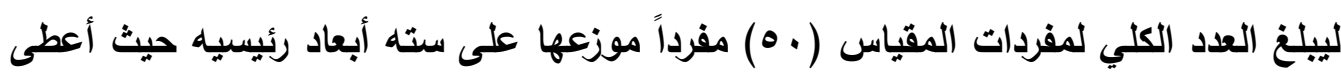

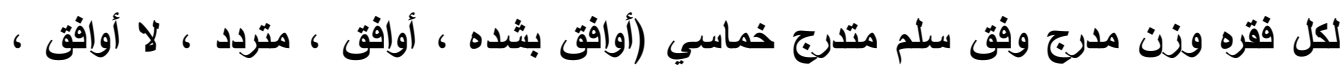

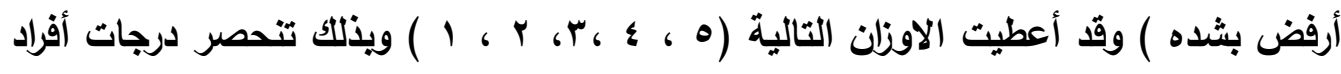

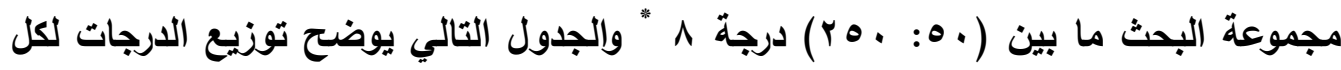

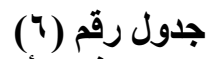

بع

توزيع درجات المقياس وفقا للأبعاد الرئيسه للتعلم

\begin{tabular}{|c|c|c|c|}
\hline مدى الدرجات & عدد الفقزات & & البعد \\
\hline $0 \cdot-1$. & 1. & دعم الرغبة في التعليم & البعد الأول \\
\hline $0 \cdot-V$ & $\mathrm{~V}$ & زياده القدرة على التعلم & البعد الثاني \\
\hline $0 \cdot-1$ & $\Lambda$ & توجيه الجهود نحو الأهداف التعليمية & البعد الثالث \\
\hline $0 \cdot-1$. & 1. & السعي الذاتي للتطوير في التعليم & البعد الرابع \\
\hline $0 \cdot-V$ & V & اطلاق الطاقات الكامنة والقدرات الخاصة & البعد الخامس \\
\hline $0 \cdot-1$ & $\Lambda$ & التعلم بفاعليه وفقا للظروف المشجعة & البعد السادس \\
\hline ro. & 0 . & & \\
\hline
\end{tabular}

ثبات المقياس:

أستخدمت الباحثة طريقه الفاكرونباخ لحساب ثبات المقياس في كل بعد من أبعاد

المقياس ككل

* ملحق رقم (^) مقياس الدافعية للتطل. 


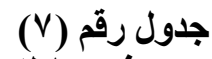

وقد جاعت النتائج على النحو الاتى:

ثبات مقياس دافعيه الطلاب للتعلم

\begin{tabular}{|c|c|}
\hline الفاكرونباخ & أبعاد المقياس \\
\hline$* *, 7 \wedge$ & البعد الأول: دعم الرغبه في التعلم \\
\hline$* *, V \psi$ & البعد الثانى: زيادة القدرة على التعلم \\
\hline$* *, 79$ & البعد الثالث: توجيه الجها نحو الأهداف التعليميه \\
\hline$* *, 7 \wedge$ & البعد الرابع: السعى الذاتى للتطوير فى التطلم \\
\hline$* *, V Y$ & البعد الخامس: اطلاق الطاقات الكامنه و القدرات الخاصد \\
\hline$* *, 71$ & البعد السادس: التعلم بفاعليه وفقا للظروف المشجعه لذلك \\
\hline$* *, 79$ & المقياس كلل \\
\hline
\end{tabular}

* * تشير إلى مستوى دلالة ه •,

يتضح من الجدول السابق أن جميع معاملات الإرتباط بالارجة لدافعيه الطلاب للتعلم

تثبير إلى مستوى دلائة ه . , . وهى دالة إحصائياً وتدل على إن مقياس دافعيه الطلاب للتعلم يتميز بالثبات مما يدعو إلى الثقة فى ثبات المقياس.

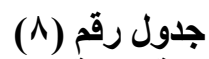

معامل إرتباط الأبعاد بالدرجة الكلية لمقياس دافعيه الطلاب للتعلم

\begin{tabular}{|c|c|}
\hline معامل إرتباط المحور بالدرجة الكلية & دافعيه الطلاب للتعلم \\
\hline$* * ., 0 \mathrm{~V}$ & البعد الأول: دعم الرغبه في التعلم \\
\hline$* * \cdot, r q$ & البعد الثانى: زيادة القدرة على التعلم \\
\hline$* *, 01$ & البعد الثالث: توجيه الجهر نحو الأهداف التطليميه \\
\hline$* * \cdot, \xi Y$ & البعد الرابع: السعى الذاتى للتطوير فى التعلم \\
\hline$* * \cdot, \leqslant r$ & البعد الخامس: اطلاق الطاقات الكامنه و القدرات \\
\hline$* * \cdot, \leqslant Y$ & البعد السادس: التعلم بفاعليه وفقا للظروف المشجعه \\
\hline
\end{tabular}

يتضح من الجدول السابق أن جميع معاملات إرتباط الأبعاد بالدرجة الكلية لمقياس

دافعية الطلاب للتعلم تثير إلى مستوى دلالة ه . , . وهى تدل على وجود الإرتباط. 
المحور الثالث: تطبيق البحث ومناقشيه نتائجه

هدفت الدراسة الميدانية إلى التأكد من فاعلية البرنامج التدريبي الذى تم إعداده وتدريب

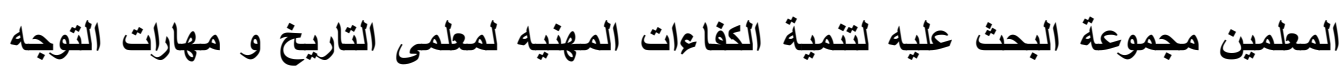

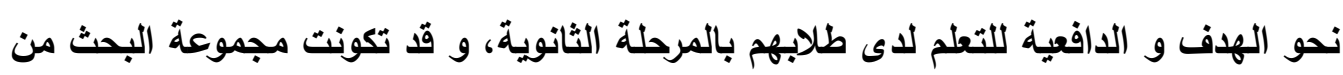

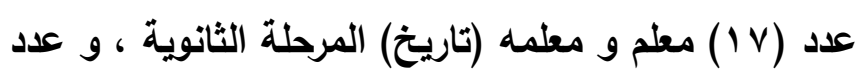

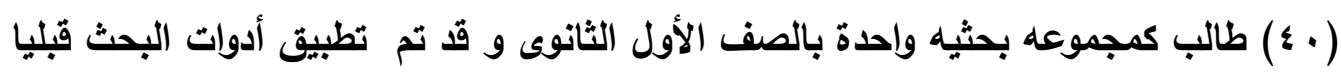

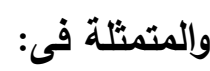

$$
\begin{aligned}
& \text { - بطاقه ملاحظه أداء المطلم } \\
& \text { - إختبار مهارات التوجه نحو الهدف } \\
& \text { - مقياس الدافعية للتعلم }
\end{aligned}
$$

كما تم تدريب المعلمين (مجموعه البحث) على التمكن من مهارات التوجه نحو الهدف و

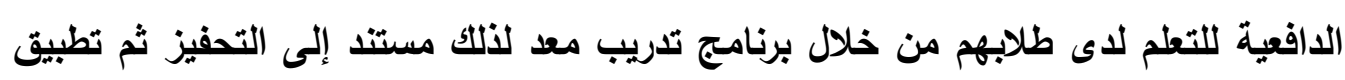

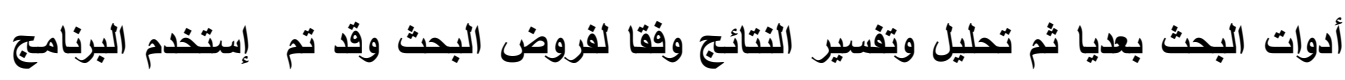

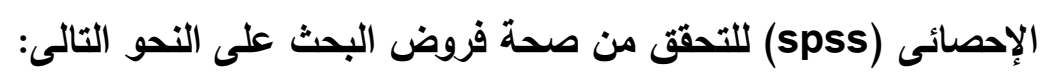

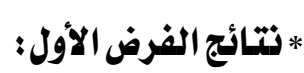
والذى ينص على أنه" يوجد فرق دال إحصائياً بين القياس القبلي والقياس البعدى القدى

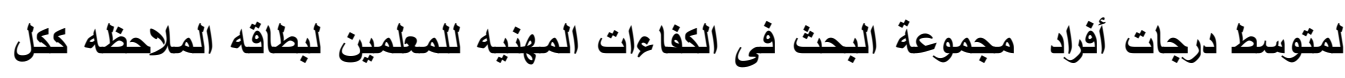

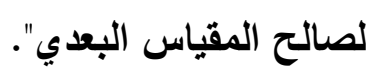
وللتحقق من صحة هذا الفرض تم إستخدم إختبار مان ويتنى للتعرف على دلالة

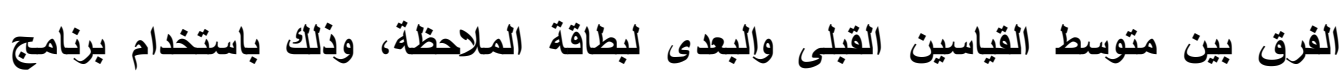

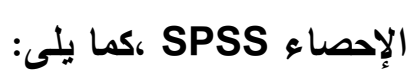

\begin{tabular}{|c|c|c|c|c|c|}
\hline مستوى الدلاكة & z قيمة & الإلحرياري & المتوسط الحسبي & العدد & بطاقه ملاحظه أداء المعلم \\
\hline \multirow{2}{*}{ دالة } & \multirow{2}{*}{$* * r, 7 r$} & $r, \cdot v$ & $r \wedge, r q$ & $1 V$ & القياس قبلي \\
\hline & & $\varepsilon, \cdots$ & $\Lambda \varepsilon, 1 V$ & 18 & القياس البعدي \\
\hline
\end{tabular}

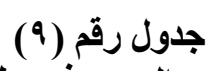

الفرق بين القياس القبلى والبعدى في بطاقه ملاحظه أداء المعلم 
يتضح من الجدول السابق، وجود فرق دال إحصائياً عند(ه . . ) بين القياس القبلي والقياس البعدي لمتوسط درجات أفراد مجموعة البحث في الكفاءوات المهنيه ككل للمعلمين لبطاقه الملاحظه لصالح المقياس البعدي، حيث بلغ المتوسط الحسابي للقياس القبلى

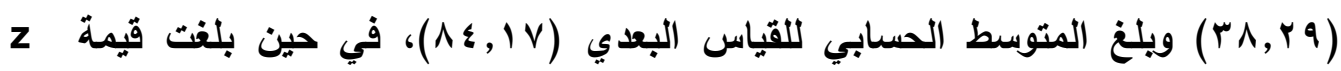

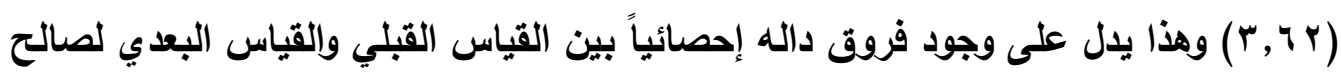

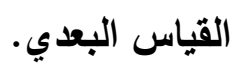

ويذلك يكون قـ تم الإجابه عن السؤال الخامس للبحث و هو " ما فاعلية البرنامج

التدريبى لمعلمى التاريخ فى تنمية الكفاءات المهنيه لديهم ؟ الاجه

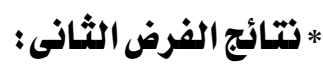
والذى ينص على أنه" يوجد فرق دال إحصائياً بين القياس القبلي والقياس البعدى

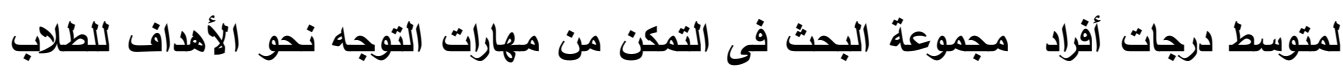
لصالح التطبيق البعدى ". وللتحقق من صحة هذا الفرض تم إستخدم إختبار" ت" T test للتعرف على دلالة الفرق بين متوسط القياسين القبلى والبعدى لمهارات التوجه نحو الأهداف ، وذلك باستخدام برنامج الاحصاء spss كما يلى:

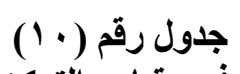

الفرق بين القياس القبلى والبعدى فى مقياس التمكن من مهارات التوجه نحو الأهداف

\begin{tabular}{|c|c|c|c|c|c|c|}
\hline الدلالة & قيمة ت & الحرية & الإلحعراف & الحستبي & العدد & التوجه نحوات \\
\hline \multirow[b]{2}{*}{ دالة } & \multirow{2}{*}{$* * r \leq, 77$} & \multirow[b]{2}{*}{ rq } & $\varepsilon, \wedge \varepsilon$ & $\varepsilon \cdot, \wedge r$ & $\varepsilon$ & القياس قبلي \\
\hline & & & 0,11 & $v 7,9 v$ & $\varepsilon \cdot$ & القياس البعدي \\
\hline
\end{tabular}

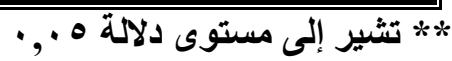

يتضح من الجدول السابق، وجود فرق دال إحصائياً عنده(ه . . .) بين القياس القبلي

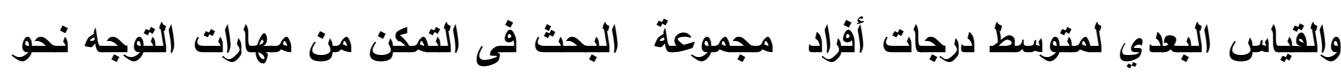

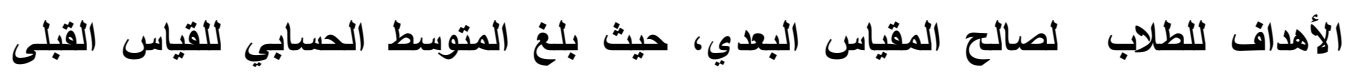

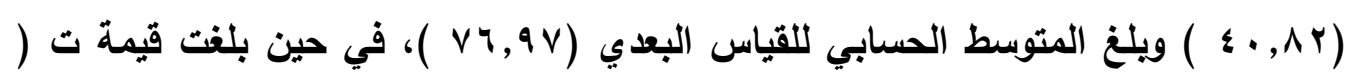




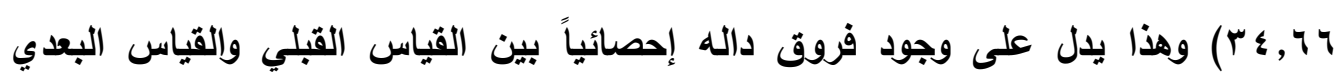
لصالح القياس البعدي.

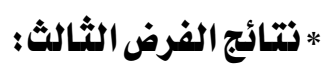

والذى ينص على أنه" يوجد فرق دال إحصائياً بين القياس القبلي والقياس البعدى

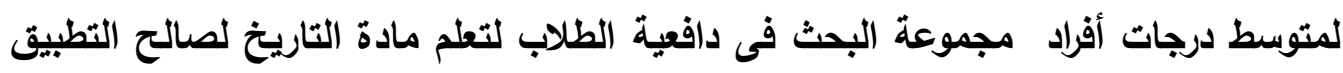

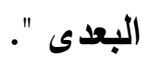

وللتحقق من صحة هذا الفرض تم إستخدم اختبار ت T test للتعرف على دلالة الفرق بين متوسط القياسين القبلى والبعدى لمقياس دافعية الطلاب للتعلم ، وذلك بإستخدام برنامج الإحصاء spss كما يلى:

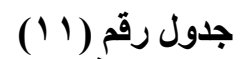

الفرق بين القياس القبلى والبعدى في مقياس دافعيه الطلاب للتعلم

\begin{tabular}{|c|c|c|c|c|c|c|}
\hline مستتوى & قيمة ت & الدرجية & الإلحعراف & الحستوسط & العدد & دافعيه الطلاب \\
\hline \multirow[b]{2}{*}{ دالة } & \multirow{2}{*}{$* * \wedge 1, r q \leq$} & \multirow[b]{2}{*}{ rq } & 0, Y YO & $I Y \wedge, \cdot V$ & 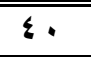 & القياس قبلي \\
\hline & & & $\varepsilon, \vee \vee$ & YrT, Yr & $\varepsilon$ & القياس البعدي \\
\hline
\end{tabular}

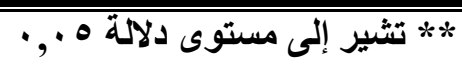

يتضح من الجدول السابق، وجود فرق دال إحصائياً عند(ه . . •) بين القياس القبلي والقياس البعدي لمتوسط درجات أفراد مجموعة البحث في دافعيه الطلاب لتعلم مادة التاريخ لصالح المقياس البعدي، حيث بلغ المتوسط الحسابي للقياس القبلى ( I I ) ويلغ المتوسط

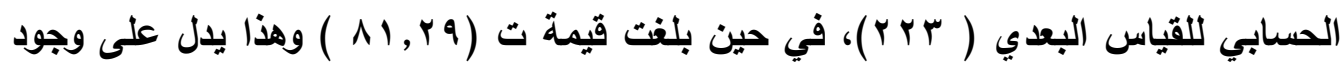
فروق داله إحصائياً بين القياس القبلي والقياس البعدي لصالح القياس البعدي. ويتضح من العرض السابق للتحليل الإحصائى فاعلية البرنامج التدريبى للمعلم فى تحقيق نتائجه ويذلك يكون قد تم الإجابه على السؤال السادس و الأخير للبحث " ما فاعلية البرنامج التدريبى على تنميه مهارات التوجه نحو الهذف و الدافعية للتعلم لاى الطلاب؟ 
*تيح من العرض السابق لنتائج البحث ما يلى: - أثبتت النتائج الخاصه بالتطبيق القبلى لبطاقه الملاحظه الخاصه بأداء المعلم ، حاجه

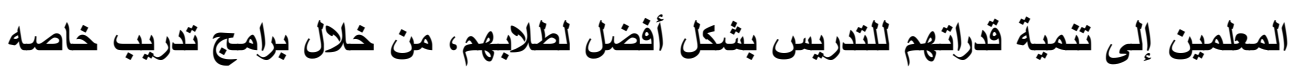
بهم تنمى مهاراتهم التدريسيه و تساعدهم على تحفيز طلابهم للتعلم. - أثبتت النتائج فاعلية البرنامج التدريبى فى تنمية قدرات المعلمين على تنمية مهارات التوجه نحو الهدف و الدافعية للتعلم لدى طلابهم وهذا ما اكده نتائج فروض البحث حيث أتضج أنه يوجد فرق دال إحصائياً بين القياس القبلي والقياس البعدى لمتوسط درجات أفراد المجموعه التجريبيه فى الكفاءات المهنيه للمعلمين لبطاقة الملاحظه لصالح المقياس البعدي. وقا برجع هذا إلحى:

O تصميم البرنامج فى ضوء الإحتياجات التدريبيه الخاصه بالمعلمين لتنمية كفاءاتهم المهنيه

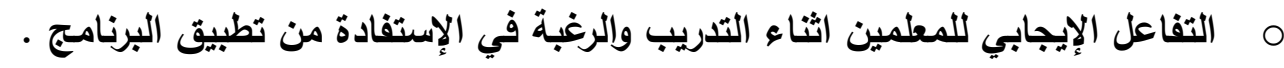
O تقدير المعلمين لأهميه تحفيز طلابهم و مردود ذلك على المتعلم من حيث إكتساب المهارات والإيجابيه اثناء التعلم.

- أثبتت النتائج الخاصه بالتطبيق القبلى لإختبار مهارات التوجه نحو الهذف الحاجه إلى التى

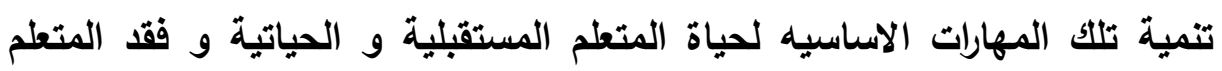
إمتلاك تلك المهارات من خلال التدريس له بأساليب التدريس التقليديه.

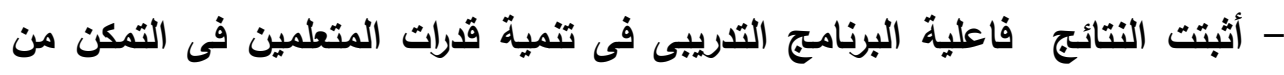

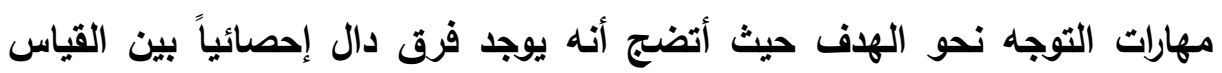
القبلي والقياس البعدى لمتوسط درجات أفراد مجموعة البحث لصالح التطبيق البعدى مما يؤكد فاعلية البرنامج التدريبى فى تحقيق الأهداف التى صمم من أجلها. - أثثتت النتائج الخاصه بالتطبيق القبلى لمقياس الدافعية لتعلم مادة التاريخ عزوف الطلاب عن دراسه المادة و صعويه حفظ محتواها نظرا لغالبيه الجانب النظرى عليها ووقوع أحداثها فى فترات زمنيه غير معاصرة لحياة المتعلم و الحاجه الى الإهتمام 
بتحديد قرات المتعلمين و أهدافهم المستقبلية من خلال العلاقات الايجابيه بين المعلم و المتعلم.

- أثبتت النتائج فاعلية البرنامج التدريبى فى تنمية دافعيه المتعلمين لتعلم مادة التاريخ حيث أتضج أنه يوجد فرق دال إحصائياً بين القياس القبلي والقياس البعدى لمتوسط درجات أفراد مجموعة البحث لصالح التطبيق البعدى و يرجع ذلك لأسلوب المعلم أنثاء تطبيق البرنامج فى تحفيز طلابه للتعلم و العمل الجماعى مما جعل منها مادة

$$
\text { ثالثا: توصعيه و زاد من دافعيه الطلاب لدراستها. }
$$

\section{فحى ضوع نتائج البحث بمكن تقدبم بعض التوصبات التالبة:}

- توصلت النتائج الخاصه بالتطبيق القبلى لبطاقه الملاحظه الخاصه بأداء المعلم إلى بـلي حاجه المعلمين إلى تنمية قدراتهم للتدريس بشكل أفضل لطلابهم، من خلال برامج تدريب خاصه بهم تنمى مهاراتهم التدريسيه وتساعدهم على تحفيز طلابهم للتعلم لذلك يوصى البحث بالإهتمام بحاجات المعلمين التدريبيه و تتمية قدراتهم للتدريس بشكل أفضل من خلال برامج تدريب تنمى مهاراتهم التدريسية و تساعدهم على تحفيز طلابهم للتعلم. - أكلت النتائج فاعلية البرنامج التدريبى فى تنمية قرات المتعلمين فى التمكن من مهارات التوجه نحو الهـف لهذا يوصى البحث بتنمية بعض المهارات الاساسية لحياة

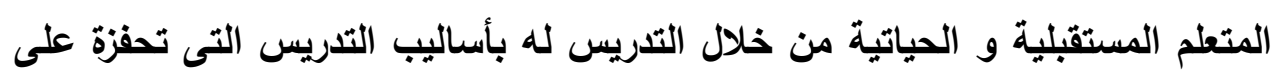
تحقيق أهدافه. - توصلت النتائج الخاصه بالتطبيق القبلى لمقياس الدافعية لتعلم مادة التاريخ عزوف الطلاب عن دراسه المادة و صعويه حفظ محتواها نظراً لغالبيه الجانب النظرى عليها ووقوع أحداثها فى فترات زمنيه غير معاصرة لحياة المتعلم لذلك يوصى البحث بالإهتمام بتحديد قرات المتعلمين و أهدافهم المستقبلية من خلال العلاقات الايجابيه بين المعلم و المتعم و أساليب التدريس الصفيه بما ينعكس على تحقيق النجاح لهم.

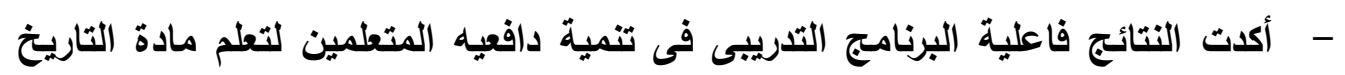
حيث أتضج أنه يوجد فرق دال إحصائياً بين القياس القبلي والقياس البعدى لمتوسط 
درجات أفراد مجموعة البحث لصالح التطبيق البعدى و يرجع ذلك لأسلوب المعلم أثناء

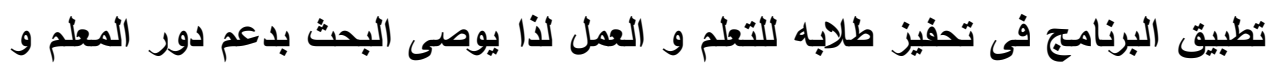
إعدادة لدفع طلابه للتعلم من خلال توظيف إستراتيجيات ومداخل تدريس حديثة.

رابعا : مقتزحات البحث

فحى ضوع نتائج البحث هناك بعض المجالات تحتاج لتوجه اهتمام الباحثين نحوها وهي: 1 - أثر إستخدم التكنولوجيا والتعلم الأليكترونى على فهم قرات المتعلم الأتيه و تحقيق نجاحاتهم المستقبلية من خلال توظيف التعلم المستتد إلى التحفيز. r - فاعليه برنامج نشاط قائم على إيجابية المتعلم و نشاطه اثثاء التعلم لتتمية مهارات الحياة و التوجه نحو أهدافه. ب- فاعليه برنامج تدريبى لمعلم الاراسات الاجتماعية لتنمية الأبعاد النفسية والثخصية لادى طلابه كجزء من واجباته المهنية.

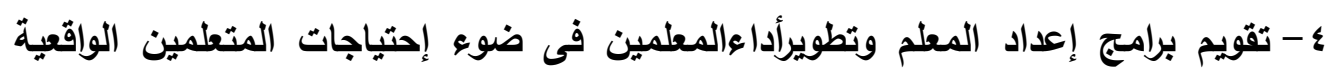
لزيادة دافعية طلابهم للتعلم و الدراسة. ه تطوير مناهج التاريخ فى ضوء إحتياجات المتعلم الفعليه و لإعدادة لمجال العمل المناسب لإحتياجاته و قدراته المستقبليه. 


\section{المراجـع}

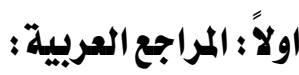

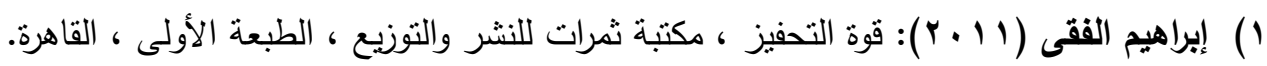

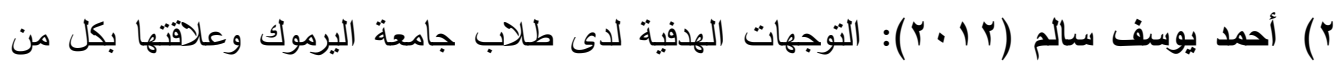

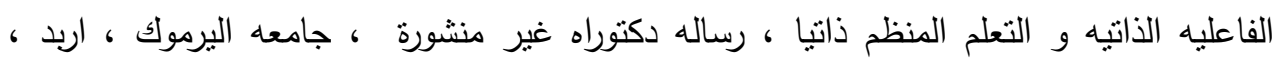

الأردن

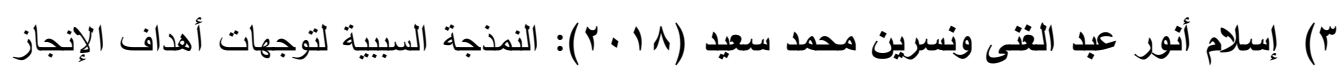

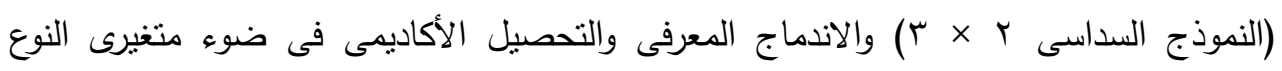

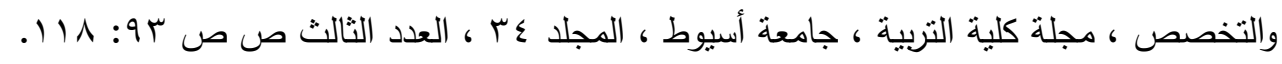

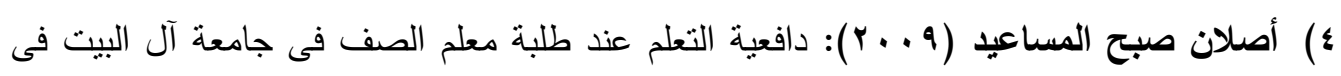

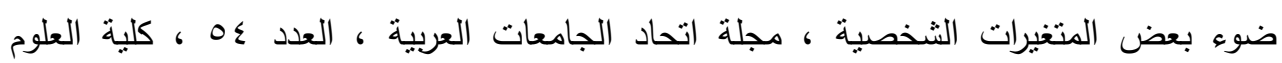

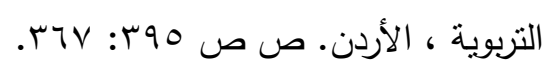

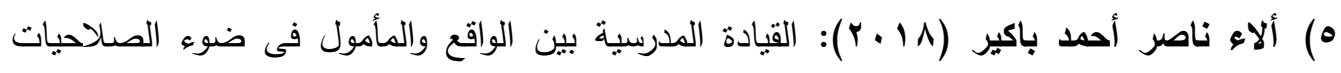

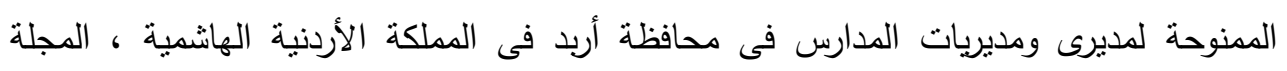

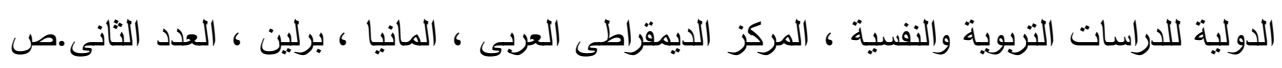

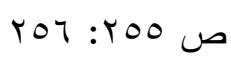

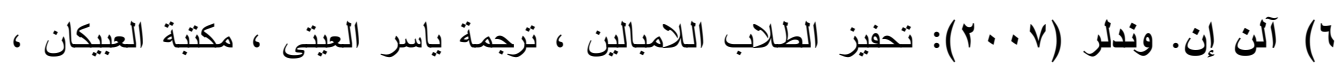

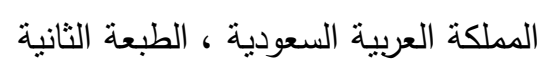

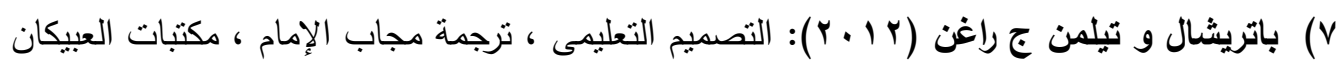

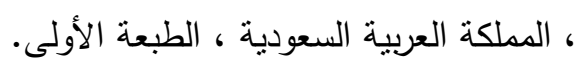

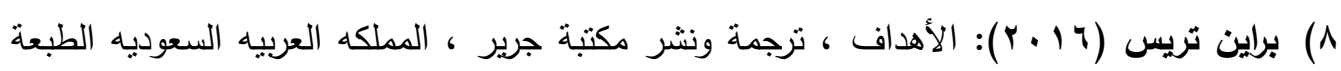
الثانية.

9) بلقاسم محمد محمد (؟ ا ب): الذكاء الانفعالى وعلاقته بالإنجاز الدراسى لاى تلاميذ التعليم

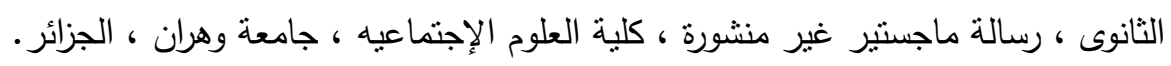

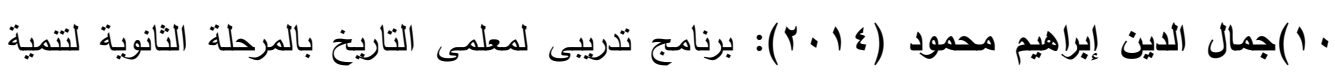

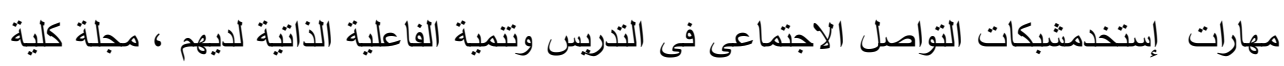

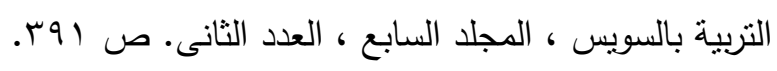


11)

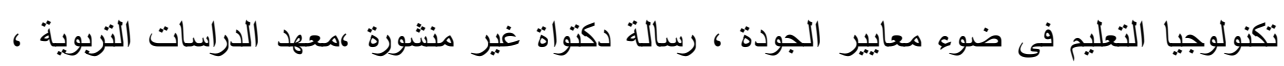
جامعة القاهرة.

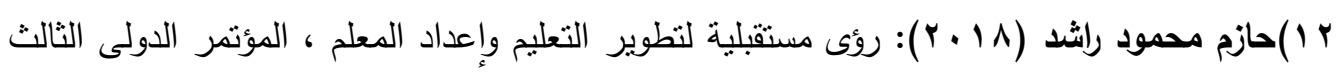

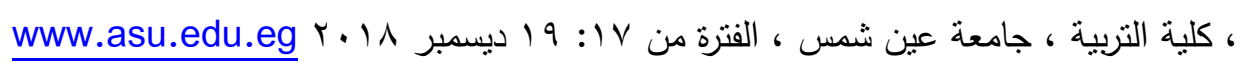

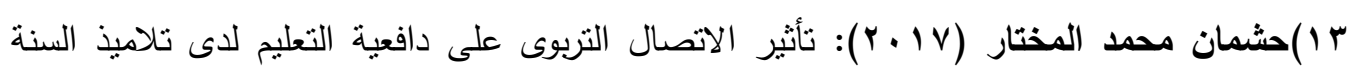

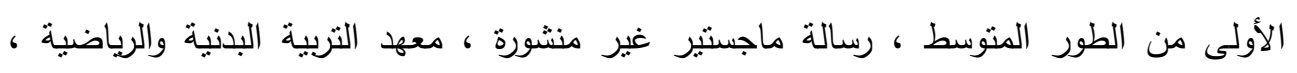

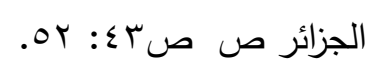

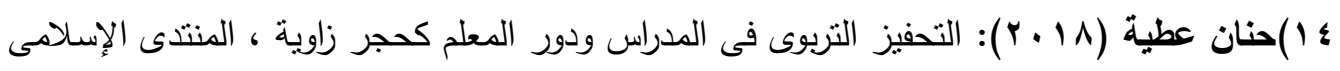
للتربية

العالمى

www.montadatarbawy.com

ه 1) خالد محمد محمود الرايغى (10 + ب): عادات العقل ودافعية الإنجاز ، مركز ديبونو لتعليم التفكير ، الطبعة الأولى ، المجلد الأول.

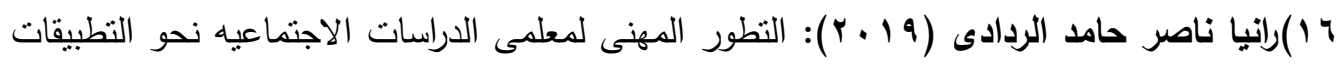

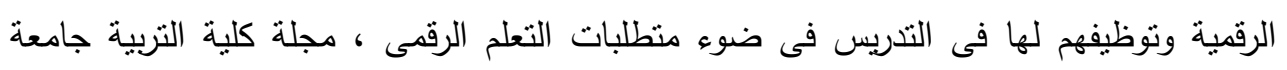

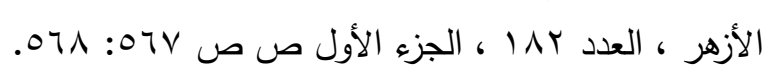

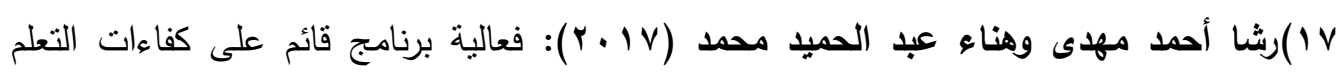

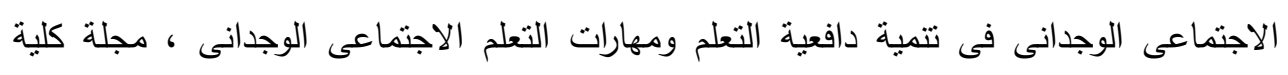

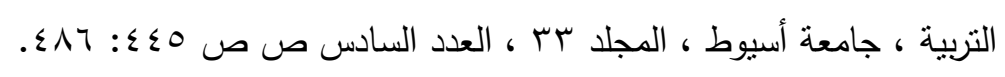

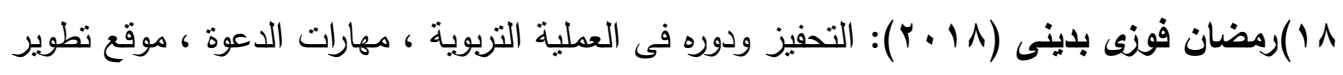

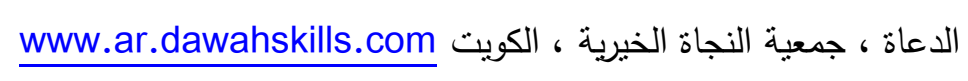

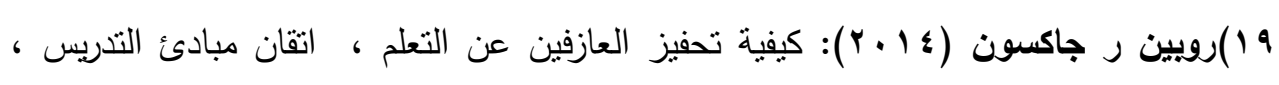
ترجمة وليد أبو بكر ، مكتبة التربيه العربى لدول الخليج ، الطبعة الأولى ، المجلد الأول.

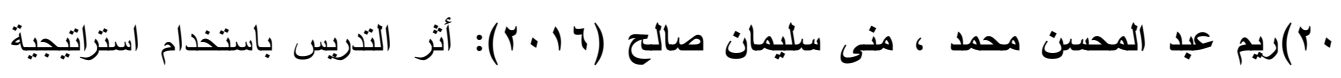

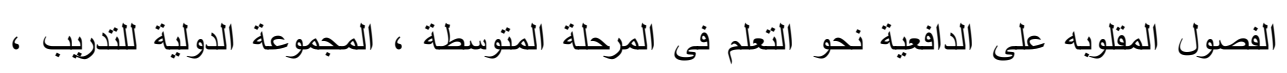

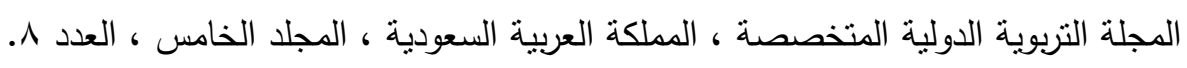

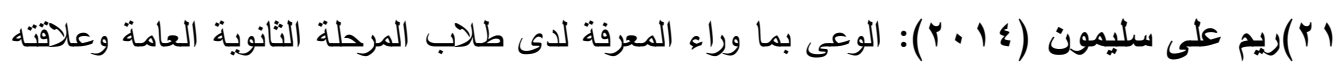

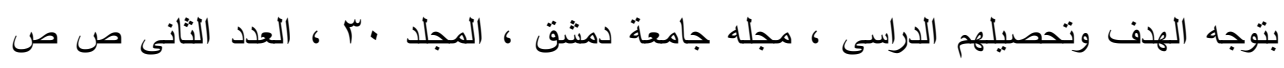




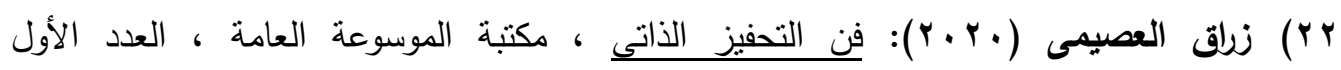
www.download.library.pdfbooks.com

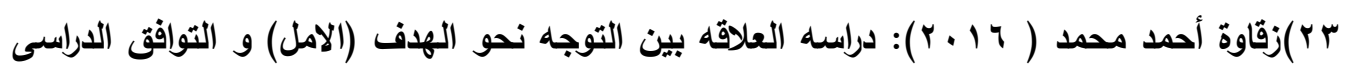
لاى المراهق فى التعليم الثانوى ، أبحثاث الملتقى الوطنى بالجزائر ، النشاطات التدريسيه بين المتعه و الملل ، المنعقد من V: 1 مارس ، جامعه وهران ، الجزائر.

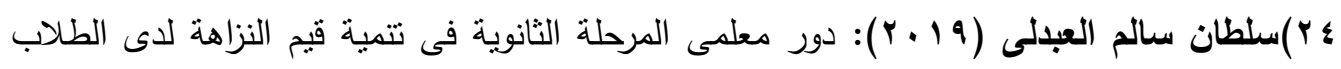
بمدينة مكة المكرمة ، رسالة ماجستير غير منشورة ، كلية التربية ، جامعة أم القرى. ه r)سهير زكى محمود سرحان (10 ب): الدافعية للتعلم والذكاء الانفعالى وعلاقتهما بالتحصيل الدراسى لدى طلاب المرحلة الإعدادية بغزة ، رسالة ماجسنتير غير منشورة ، كلية التربية ، جامعة الأزهر

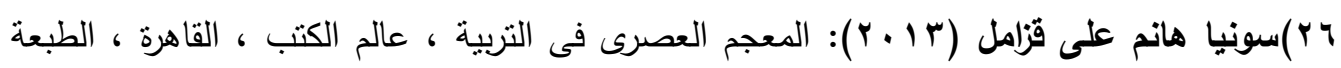
الأولى.

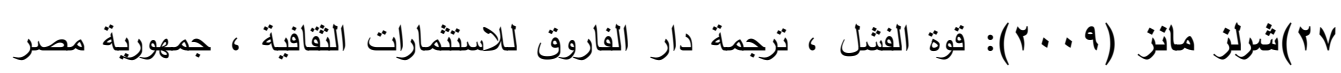
العربية ، الجيزة ، الطبعة الأولى.

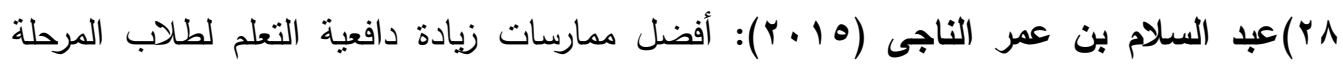
الثانوية فى ضوء إثباع حاجاتهم الإنسانية ، مجلة دراسات عربية فى التربية وعلم النفس ، رابطة

$$
\text { التربوبين العرب ، العدد } 7 \text { V. }
$$

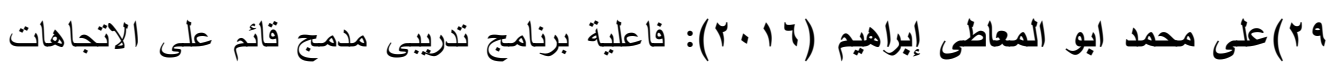
المهنية لتتمية الااء التدريسى والاتجاه نحو مهنة التدريس لدى معلىى الدراسات الإجتماعيه بمرحلة

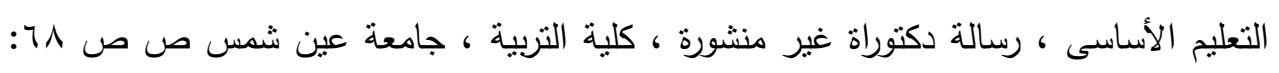
.ᄉ.

• ب)على مصلح المطرقى (T 1 • r): إعداد وتدريب المعلم فى ضوء مطالب التتمية ومستجدات العصر

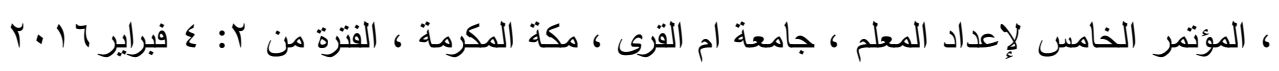
www.aljazirah.com

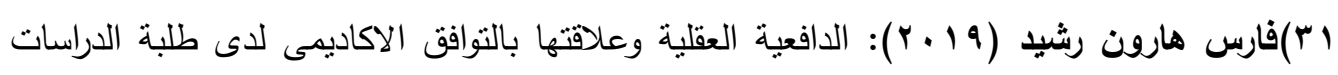

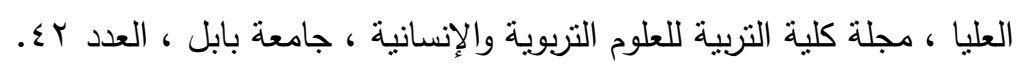

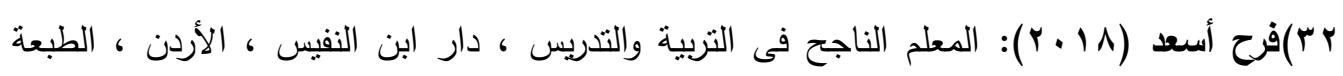
الأولى. 


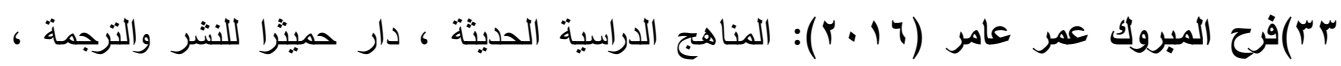
القاهرة ، الطبعة الأولى.

ع ب)فرح المبروك عمر عامر (؟ ا • r): طرائق التدريس العامة ، دار حميثرا للنشر والترجمة ، القاهرة ، المجلد الأول ، الطبعة الأولى.

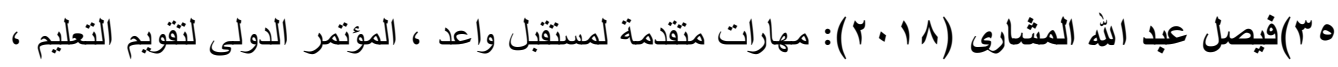

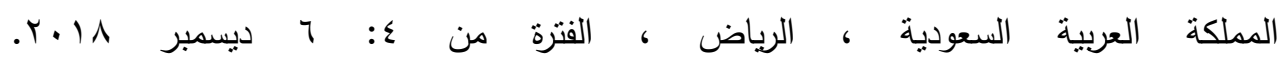
www.drive.uqu.edu.sa

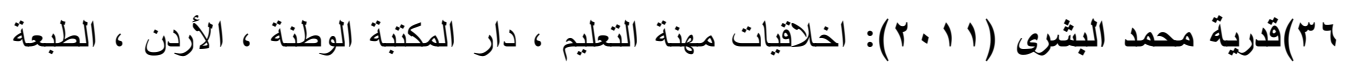
الأولى.

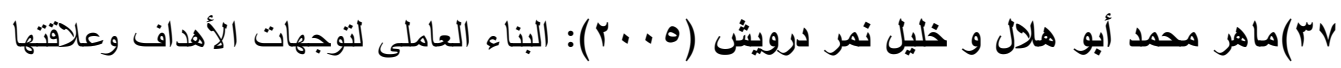
بالتحصيل الدراسى لدى طلبة المدارس وطلبة الجامعة: دراسة للافعية فى إطارى علم النفس الاجتماعى والثخصية ، دراسات العلم الإنساية والإجتماعيه ، المجلد بم ، العدد الأول www.journals.ju.edu.jo

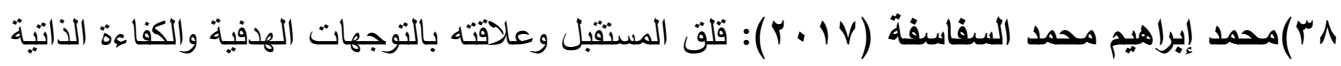
المدركة لدى الطلبة الخريجين فى جامعة مؤنة ، مجلة البلقاء للبحوث والدراسات ، جامعة عمان

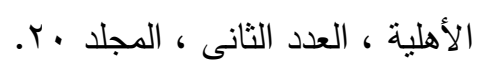

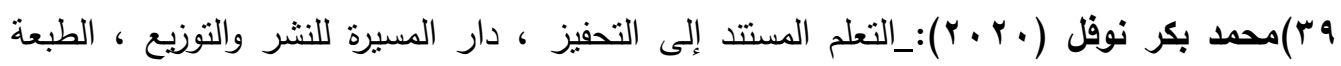

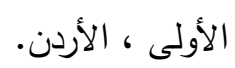

• ع)محمد عادل عبد العزيز (11 (Y): قوة التفكير الإيجابى ، جمعية وادى التكنولوجيا ، الطبعة www.wadytec.org الأولى

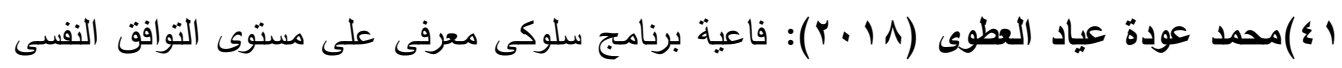
والاجتماعى لخفض الرغبة فى التسرب الدراسى فى المرحلة الثانوية ، دار اليازورى العلمية للنشر

$$
\text { والتوزيع }
$$

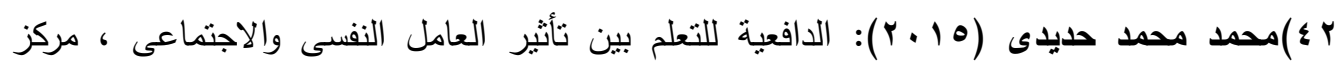

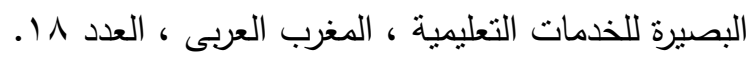

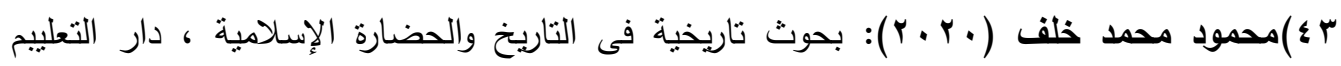
الجامعى ، الإسكندرية ، الطبعة الأولى.

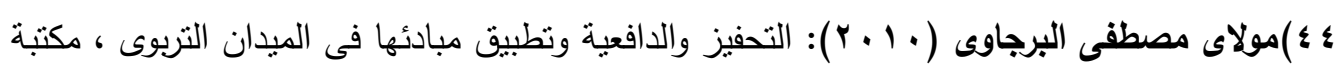
الألوكة ، شبكة الألوكة الإلكترونية 


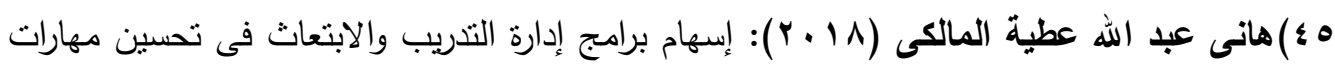

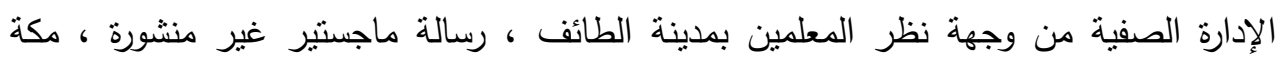

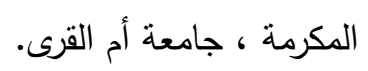

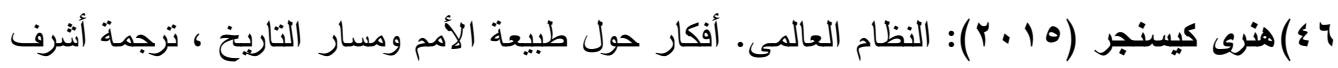

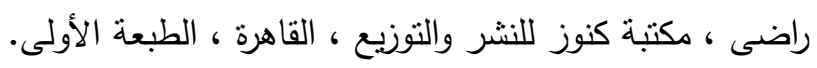

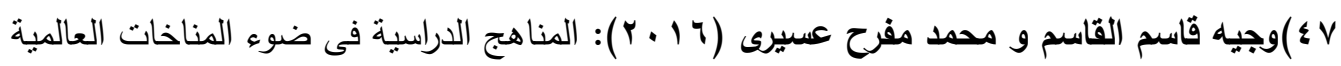

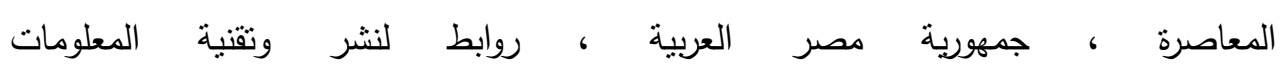
www.books.rawabt.com

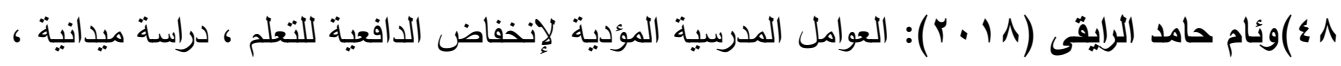

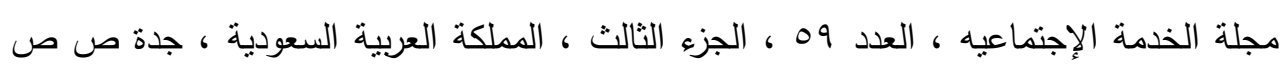
. $\leqslant \leqslant: 17$

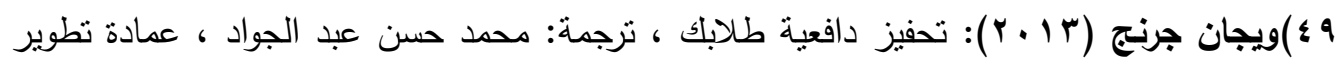

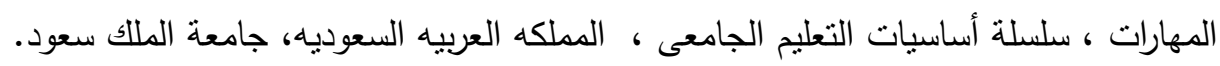

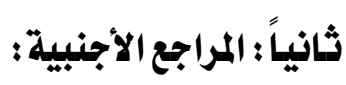

1) Babenko, Oksana, Daniels, Lia M, White Jonathan Oswald and Anna, Ross Shelley (2018): Achievement Goals of medical students and physicians, Educational research and review, v 12, n 2, pp 74:80.

2) Bruhn, Allison Leigh, Fernando, Josephine, Mc Danial, Sara and Troughton, Leonard (2017): Putting behavioral Goal-setting research into practice, v 26, n 2, pp 66:73.

3) Bruhn, Allison, McDanial, Sara, Fernando, Josephine and Troughton, Leonard (2016): Goal setting interventions for students with behavior problems: A systematic review, behavioral Disorders, v 41, n 2, pp 107: 121.

4) Cushman, Kathkeen (2014): 8 conditions for motivated learning journal, delta kappan, v 95, n 8.

5) Davion, Johnson (2017): The role of teachers in motivating students to learn, BOU journal of graduate students in education, v 9, $\mathrm{n} 1$.

6) Erthel Severine (2016): the effects of Goal-oriented instructions in Digital Game Based Learning, Interactive Learning Environments, v 24, n8, pp 1744.

7) Gerard Libby, Ryoo, Kihaney, Kevi, Liu and Lydia, Rafferty (2016): Automated guidance for student inquiry, journal of educational physiology, v 108, n 1, pp 60:81. 
8) Gross, Heathery J (2019): goal setting, Goal teaching, celebration of success and student self-efficacy in writing, Dpro Guset LLC, EdD Dissertaltion, William Woods University, non journal, p 106.

9) Gutsu, Demeneve, Kochetove, Mayasova and Bellinova (2016): Studying Motivational-Axiological of professional Competence of a College teacher, International journal of environmental and science education, v 11, n 18, p 1265.

10) Hornstra, Lisette, Kamsteeg, Antoinette, Pot, Sara and Verheij, Lydia (2018): A Dual pathway of student motivation, combining and implicit and explicit of student motivation, frontline Learning research, v 6, n 1, pp $1: 18$.

11) Hwang, Keumoong Meyer and David Samuel (2019): Relations the aim of education in Joseon Neo-Confucianism, D the case of the five relationships, Educational philosophy and D theory, v 51, n 9, pp 936:949.

12) Joseph Zajda (2018): Motivation in the classroom creating effective learning environments, Education practice and theory, v 4, n 2, p 102.

13) Karabag Kose, Esra (2019): Development and Psychometric, properties of teacher classroom leadership scale, Online submission, educational Administration, theory and practice, $\mathrm{v} 25, \mathrm{n} 1, \mathrm{pp}$ 139:168.

14) Karam duman, Hidir (2017): Social studies teacher candidates, opinions about Digital Citizenship and its place in social studies teacher training program. A comparison between the AUS and Turkey, Turkish online journal of educational Technology, TOJET, v 16, n 2, pp 93:106.

15) Kim Eun, Park Sunyoung and Kang Hey Sesung (2019): Support, Training readiness and Learning Motivation in determining intention to transfer, European Journal of training and Development, v 43, n 3, p 306.

16) Koca, Ftih (2016): Motivation to learn and teacher-student relationship, journal of international education and leadership, v 6, n2, p 20.

17) Lobos Bustis and Cloudio AleJandro (2019): Impact of Teacher training on academic self-accept and educational outcomes, electronic journal of research in educational psychology, v 17, n 49, pp 519:540.

18) Miele, David and Schder Abigail (2018): The of metamotivational monitoring in motivation regulation, Educational Psychologist, v 53, n 1, pp 1:21.

19) MIkami, Yuka (2020): Goal setting and learners, Motivation for extensive reading forming avirtuous $\mathrm{Cycle}$, reading in foreign language, $\mathrm{v} 32, \mathrm{n} 1, \mathrm{pp}$ 28:38.

20) Miklan Kova Ludmila (2018): Education of children in the area of physical activities of a foundation for life long sports, journal of education and training studies, $\mathrm{v}$ 6, n 1 .

21) Nadon, Danial, Samson, Andre, Gazzola, Nicola and Theriault, Anne (2016): Becoming a guidance counselor in Ontario, formative influences 
from oursellors perspective international journal for educational and vocational guidance, v 16, n $3, \mathrm{p} 15$.

22) Nordengren, Chase (2019): Goal-setting practices that support a learning culture, Phi Detta Kappan, v 101, n 1, p 19.

23) Pramita, Pramisti, Sharma, Unmesh and Anderson, Angilka (2020): Effective teacher professional Learning on classroom Behaviour Management, A review of Literative Australian Journal of teacher education, v 45, n 1, pp 61:81.

24) Schum, Maximillia and Bogner, Franz (2016): Measuring Adolescent Science Motivation, International journal of science education, v 38, n 3, pp 434:449.

25) Sumaryanta, Mardapi, Djemari, Sugiman and Her wan Tutat (2019): Community-Based teacher training; Transformation of sustainable Teacher empowerment Strategy in Indonesia, v 21, n 1, pp 48:66.

26) Tasi, Chia Hui, Cheng Hsue and Duen Yian (2017): Can learning motivation predict learning achievement, case study of a mobile game based learning, Education and Information Technology, v 22, n 5.

27) Tentama Fatwa, Mohameed Hassan Abdrllah (2019): Motivation to Learn and Social Support Determine employability among vocational high school students, international Journal of evaluation and research in education, v 8, n 2, pp 237:242.

28) Washbun,Nicholas, Rchards, Andrew and Sinelnikov, Oleg (2020): The Development of US physical education teachers motivating styles, A socialization perspective, European physical education review, v 26, n 2, p 514.

29) Yin Hongbiao (2016): Teacher motivation Definition, research development and implications for teachers, Cogent education, v 3, n 1, p 18. 